\title{
AUTOBIOGRAPHICAL NOTES \\ OR \\ FUN WITH FIELD WORK
}

BY

ROGER B. CLAPP 1

\section{EARLY YEARS}

My interest in birds developed early. My father had a habit of dragging his children along on hikes to various local points despite our (I am the eldest of five) basic disinterest in same. Once, when I was about five, I was riding along on my father's shoulders, while making faces at my sister Judy, who had just relinquished the favored position. Suddenly a brilliant red bird flew across in front of us in the forest ahead. I instantly demanded to know what it was, but my father, who had once worked as a forester's assistant, knew a good bit about trees but very little about birds. For some reason this irritated me unduly and I became very determined to be able to identify birds. Parenthetically, considering the locality (Connecticut) and habitat, the bird was almost certainly a male Scarlet Tanager (Piranga olivacea).

Not too long after that incident, my grandmother gave me one of the Chester A. Reed pocket guides to birds. At $3 \times 5$ inches and with red, blue, green, and yellow covers, these guides provided truly vile illustrations of birds and some descriptions, so bad that my ambitions were put on hold for some time, although my interest in the outdoors became greater as did my willingness to go on walks with my father, with whom otherwise, I never got on that well.

It was not until I was 11 (1949) and in sixth grade that my interest in birds once again became acute when a schoolmate on the bus showed me the first edition of Peterson's Field Guide to Eastern Birds. I knew that I had to have the book and later obtained it when I traded my entire stash of comic books, some 80, to obtain it. The schoolmate felt a bit cheated as some were coverless, but I wasn't about to return the book.

Thus enabled, I spent many long hours tramping through the fields and forests of Connecticut attempting to identify birds and often accompanied either by my dog, Rex, or by my cat, Sam. The frustration of trying to identify relatively common birds with any certainty was leavened by an occasional triumph such as my first encounter with Pine Grosbeaks (Pinicola enucleator). I was en route to visit some friends in Amesville (or Sugar Hill as it was known locally for the abundance of sugar maples there), tramping through 18 " of snow. Suddenly I encountered some robin-sized birds, some wine colored (males as I later learned) and others more rusty, sitting atop the snow.

1. Biological Survey Unit, U.S. Geological Survey, Patuxent Wildlife Research Center, National Museum of Natural History, Washington, DC 20560-0111. 
What fascinated me was their incredible tameness that allowed me to get within a very few inches before they took flight.

I remember high school, which I regarded as only a little less dreary than grammar school, mostly because of various birding jaunts. During one winter my family was quarantined because all five of us had the mumps and I managed to spend nearly eight weeks watching a trolly feeder that I had made. The continual opportunity for reinfection led me to the distinction of having had mumps three times, first on one side, then the other, then again on the first side.

I have never liked school (or generally regimentation of any sort), but I have always liked learning new things so high school was not entirely boring. Among the various subjects taught, I found the courses in science and English the most interesting, the latter due to the skills of one teacher, Arthur Kobler ("The Cobra"), who lived at the far end of the street on which I lived in Amesville. He actually challenged the students to learn something and was a dynamic teacher in whose classes I actually did not read something else hidden inside my school books.

My interest in birds led me to the practice of taking off Fridays during my senior spring (my mother was always willing to write an excuse). The area in which I birded, along a stretch of road leading to Canaan, had much marshy ground and a swamp that made it fairly good for shorebirds, at least those few that frequented inland Connecticut, but was one along which a number of my teachers commuted to school. At first, I tended to duck out of sight if I saw one coming, but later became emboldened enough to wave to them as they went to work. Eventually I was called on the carpet by the principal who mildly asked me whether it might not be better if I came to school. I replied that I thought not as I was, as he knew, getting straight A's and was the school's first National Merit Scholar as well. He seemed a trifle irritated, but nothing more was said and I continued Friday birding. I eventually ended up as salutatorian, something I would have just as soon done without, but as I scored so highly on a general knowledge test given that senior year that I was pulled up from sixth to second in my class.

During that year I also invited Aretas A. Saunders to give a talk to our science club. Saunders, one of the first authors to produce a guide to the songs of wild birds (1951), and I had a fine time, particularly because I could identify many of the songs which he was a virtuoso at imitating. The rest of the science club was not so entertained, however, as most were geeks interested in rockets and other mechanical hardware. Following this meeting, unbeknownst to me, Saunders nominated me for a student membership in the American Ornithologists' Union whose periodical "The Auk" gave me a good notion of what constituted scientific ornithology in those days.

Because that was the first year of the National Scholarship Program, I received more publicity than I desired and my half-formed notions of going into conservation in some manner led to strangers accosting me in the A\&P Store in Lakeville, where I worked summers to earn some spending money. All seemed seriously worried that I was not going into law or medicine or something that would make much money, but this has never been a major concern for me, and I managed to be polite to all my presumably misguided well-wishers. 


\section{COLLEGE DAYS}

I had applied only to Cornell, which I knew had an ornithology program, despite the suggestions of the guidance counselor that I apply elsewhere as well. I felt, not unjustifiably, that my grades and National Merit Scholarship would ensure my acceptance there, which indeed occurred. What I did not expect, during my freshman orientation, was to discover press notices mentioning my presence there in Fernow Hall where the field vertebrate zoology classes were held. I had hoped to be relatively unnoticed, drop back to a gentleman's $\mathrm{C}$, and spend more time pursuing my interests, but I found this was not to be.

During my first year, while I was taking introductory ornithology, mostly because I thought I knew enough about birds to get an easy A, I went out on one of the few class field trips led by a graduate student as well as our eminent professor, Charles G. Sibley. While on this trip and mostly talking with a friend, I kept calling out identifications of various birds that we heard, usually a split second before the doubtlessly somewhat annoyed professor did. Nonetheless, following the field trip he asked me to come to his office, which I did. He queried me about my future intentions, which were pretty nebulous and something on the order of becoming a forest ranger. Sibley convinced me that it would be worthwhile to attempt to become an ornithologist, a decision that changed my life forever.

As a freshman I much desired to do field work. Another student, Craig Smith, and I braced Sibley about taking a trip to the Amazon. (We lacked money, but Sibley always had a major talent for obtaining grants). Sibley was not convinced and suggested that we instead go to Mexico to collect hybrid towhees in the mountains and to take a look at the lowlands during the last week of our expedition. To lead this expedition, he chose Fred C. Sibley, a graduate student, who had previously worked for Charles Sibley collecting hybrid buntings and orioles in the Great Plains. Fred was a markedly skilled field man who was not only good at handling the logistics of the truckbased survey, but also unusually able at collecting and preparing birds.

This expedition undertaken during the summer of 1958 markedly changed my opinion about becoming an ornithologist because it turned out I liked field work extremely well. To my surprise, however, the mountains where we were collecting Collared Towhees (Pipilo ocia) and Spotted Towhees (Pipilo erythrothalmus maculatus) and their hybrids were both high and cold and I remember being strongly impressed by a shower of pellets of frozen snow during one July morning. I was somewhat disappointed in the bird life at these heights of 9000-11000 feet because many of them were the same species (if not the same subspecies) as the dooryard birds, e.g. Eastern Bluebird (Sialia sialis) and American Robin (Turdus migratorius), that I had known in northwestern Connecticut.

The lowlands were another matter, however, and I was thrilled to see my first Amazon parrots flying to roost along the Rio Corona (Fig. 1) in Tamaulipas in the same area mentioned and then immortalized by George C. Sutton $(1951,1972)$ in books reporting his visits there. In other areas one could easily become fascinated by exotic fare such as motmots, trogons, jacanas, thickknees, and an astonishing variety of hummingbirds. 


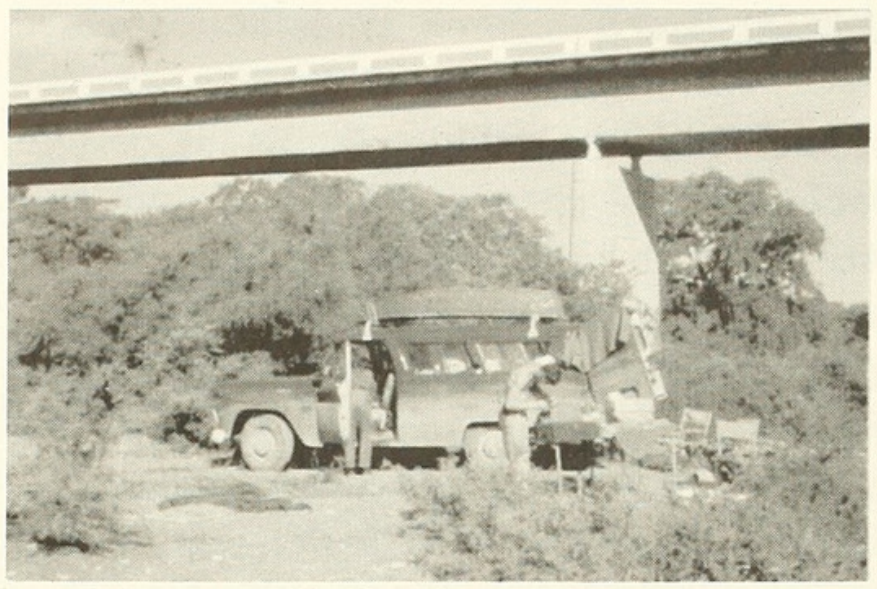

Figure 1. Camp on the highway near the Rio Corona. June 12, 1961.
The work in Mexico was not without hazard, however. During the following summer when Fred, Sid Tamm, and I returned for another session of collecting mountain hybrids, I mistakenly did not check my sneakers for visitors and an inch-long black scorpion jumped out and stung me in the chest. Not only was it extremely painful, but I found, to my horror, that it had also completely stopped my breathing reflex. I realized that I was in considerable trouble and went for help from my colleagues, humping along on my back like a giant earthworm to where they were preparing breakfast outside the tent. To my panic and incredible disgust, neither of my colleagues could tell what was happening and kept asking "What is wrong, Roger?" when it was pretty obvious to me that I was not breathing and couldn't tell them anything. My thoughts, considering I was afraid I might die, were not very charitable, but as everything was fading to black the breathing reflex kicked back in, much to my relief. I had a hard time even speaking to the others for the rest of the day, but I never again made the mistake of not inspecting my footgear with some care.

Later during the trip another incident led me to reflect on the hazards of field work. As we were preparing bird skins in our tent near a road on the Isthmus of Tehauntepec, we heard a sudden popping sound which lead me to turn to Fred and say "firecrackers?" just as Fred grabbed his leg with an exclamation. As it turned out, someone had emptied a .22-caliber rifle into our tent and had gotten Fred. Later I examined where I had been sitting and saw a hole about 6" above where my head had been. While Sid drove Fred to town I waited more than a little nervously for their return, shotgun in hand, but fortunately encountered no one. That humid night, with hundreds of enormous fireflies drawing large J's through the air, is certainly one that I never will forget.

Sibley's interests had gradually turned from the study of hybrid birds to the study of egg- white proteins as a better indicator of the relationships of higher taxonomic categories of birds. As one of his students I took to collecting eggs for him with some enthusiasm, but perhaps not with the deviousness that led him to some trouble with British authorities. Nonetheless, I remember once anchoring David West, then a graduate student, while he with his great height and long arms removed Cliff Swallow (Hirundo pyrrhonota) eggs from their nests under the eaves of a New York barn, while Sibley kept the farmer engaged in conversation where he could not see our depredations.

During the spring I continued to get eggs for Sibley with some enthusiasm, and quite openly, which led to me becoming persona non grata with the staff of the Laboratory of Ornithology at Sapsucker Woods where it was believed I was the one who emptied all their nest boxes one fine day. Actually, I was innocent of their accusations, 
although I did know who had taken the eggs. At the time, I thought taking eggs from nest boxes was really not sporting.

Nonetheless, I was guilty of removing all the Common Grackle (Quiscalus quiscula) eggs from their nests in the park at the head of Lake Cayuga, later learning that this colony was part of a doctoral study by Robert W. Ficken. I also collected a clutch of Black Tern (Chlidonias niger) eggs from a floating nest at Spencer Marsh to which I had to swim and return with the eggs in my mouth. I later learned that this was apparently the first known nesting there in some years. Thus, one can see the basis for the suspicion with which I was greeted by the less collecting-oriented ornithologists and students.

On the last of our trips from Cornell to Mexico (and British Honduras) our goals were to collect egg-white protein for Sibley's studies. To this end the three of us, myself, John S. Weske, and Martin Michener, proceeded southward in the spring of 1961. The others' knack for finding nests and eggs was not great, unfortunately, but we had a few successes, including one stop in the lowlands at Isla, Veracruz (Fig. 2), where the fence posts were composed largely of small living trees that had begun regrowth at the top, providing an almost perfect nesting place for nesting birds (Fig 3). Almost one of every five posts had a small flycatcher's nest, mostly Vermillion Flycatchers (Pyrocephalus rubinus), Tropical Kingbirds (Tyrannus melancholicus) and Social Flycatchers (Myiozetetes similis), but also an occasional nest of the Fork-tailed Flycatcher (Tyrannus savana), Derby Flycatcher (Pitangus sulphuratus) and Duskycapped Flyatcher (Myiarchus tuberculifer). Here, Martin distinguished himself by finding a clutch of Double- striped Thick-knee (Burhinus bistriatus). Our take for the day was about 60 eggs (Fig. 4), less impressive than one might think because it was relatively late in the breeding season and most of the eggs, when opened, proved to be too incubated for use in protein studies.

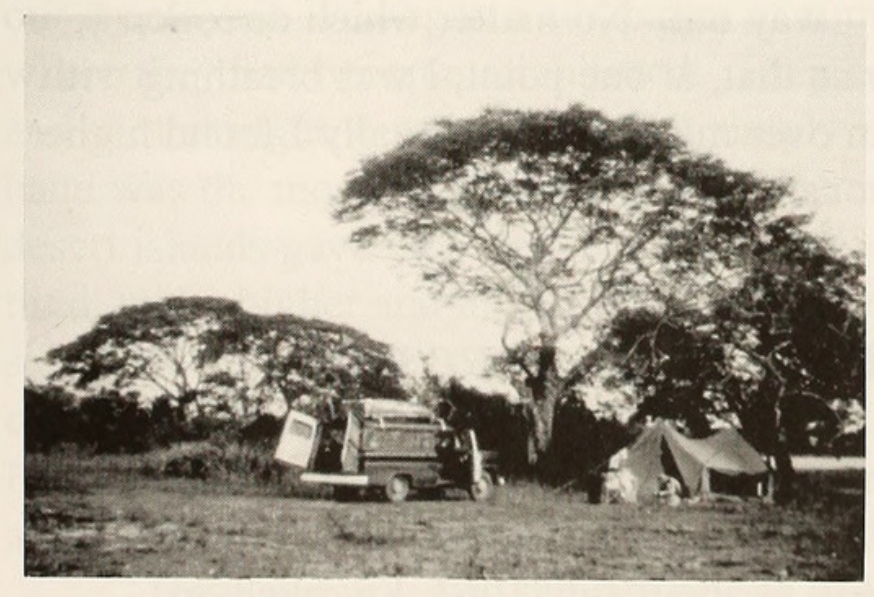

Figure 2. Our campsite at Isla, Veracruz.

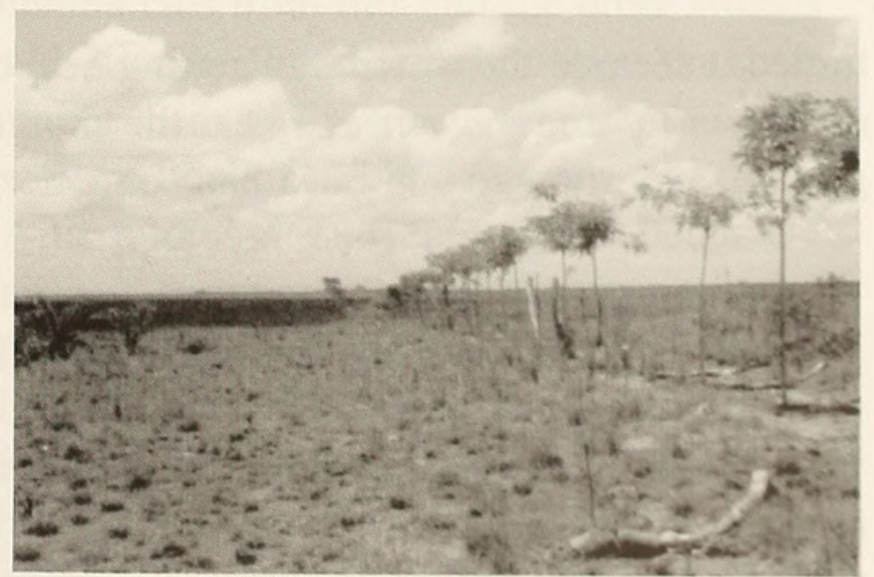

Figure 3. Flycatcher nesting habitat, Isla. Jun 17, 1961.

Another technique for getting nests was using heavy loads of shot shells to shoot down hanging bird's nests. One person would sever the branch on which the nest (usually Rose- throated Becards (Platypsaris aglaiae) hung, and another person would catch the nest before it hit the river or ground as the case might be (Fig. 5). This 


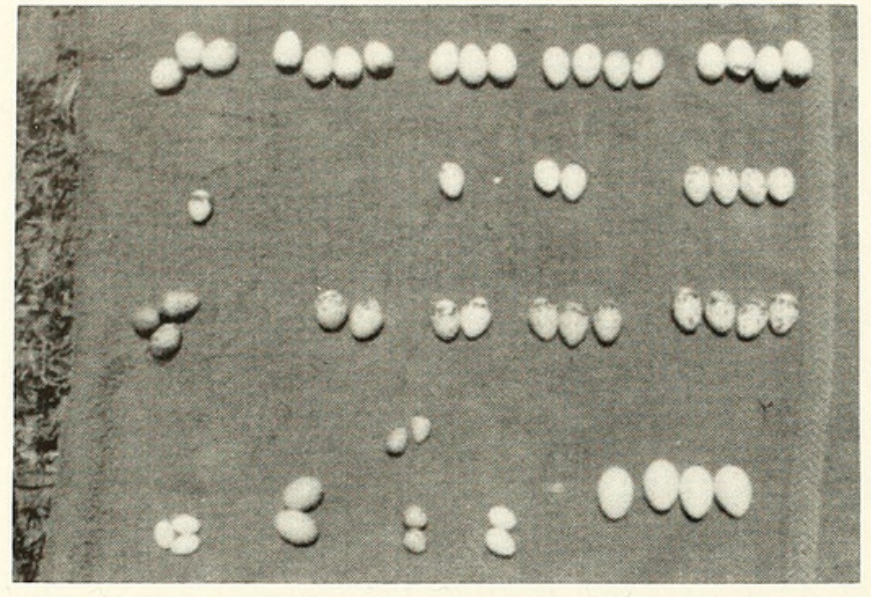

Figure 4. Eggs collected on our best day, 17 June 1961, at Isla, Veracruz.

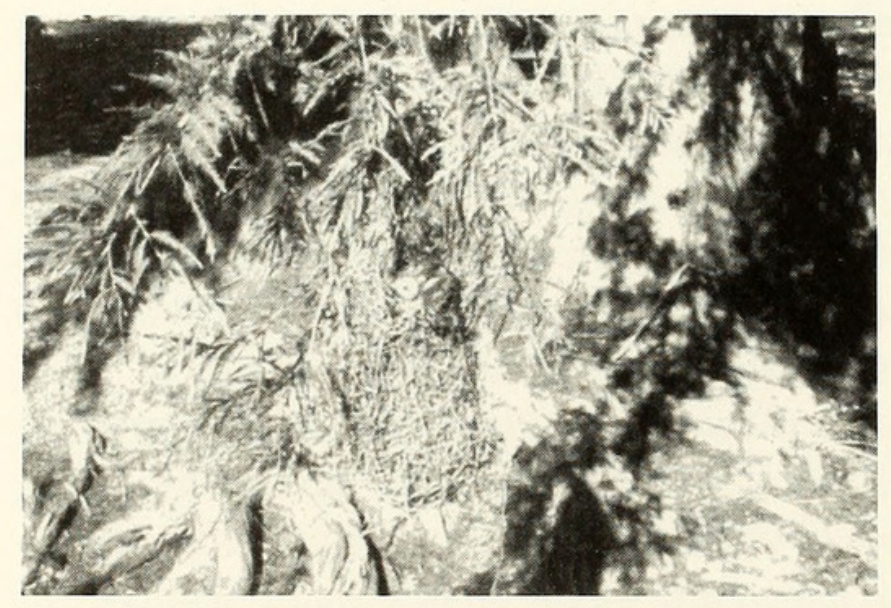

Figure 5. Becard nest obtained by shotgun, Rio Corona, Tamaulipas, Mexico. June 13, 1961. procedure was effective, if one managed to catch the nest, but resulted in getting many nests with young becards that did not survive.

This trip perhaps was the one that solidified my interest in bird eggs and nesting biology, an interest I maintain to the present day. I often think that I was born about 50 years too late as I certainly would have been an enthusiatic oologist, back when such activities were more respectable.

As we traveled through Campeche on 16 July, we stopped to view a heron colony that had been mentioned in Edwards (1955) guide to finding birds in Mexico. Deciding to go into the colony, some distance from the road, to check for eggs we found not only American Egrets (Casmerodius alba) and Anhingas (Anhinga anhinga), but also Agami Herons (Agamia agami), then unknown for the area (Michener et al. 1964). I returned with a shotgun to obtain some of these herons. Once within the colony I quickly got lost and could not find my way out. No matter which direction I

turned it seemed the water was getting deeper so that, at one point, I was breathing with my upper lip under water as I held the shotgun over my head. Eventually I found higher ground, and my way out, but I had some nervous moments for awhile.

\section{INTO THE PACIFIC WITH THE PACIFIC PROJECT}

After college, I heard of a project at the Smithsonian Institution to study the fauna and flora of the central Pacific Ocean. I applied for a job and to my delight got one as a technician. Arriving at the Smithsonian in about July 1963, I worked on various preparations while anxiously awaiting a chance to go into the field. This chance came in October 1963 when I flew to Honolulu to participate on the third of the SIC (Southern Island Cruises). They were SIC(k) cruises for many indeed. Fred Sibley, once again our fearless leader, maintained a staunch, but slightly green color, on the foredeck (Fig. 6) but I was pleased to discover on this trip and others that I am apparently immune to seasickness. Instead of getting sick, I get sleepy, usually sleep for 10 or 11 hours, and then I am troubled no more. 


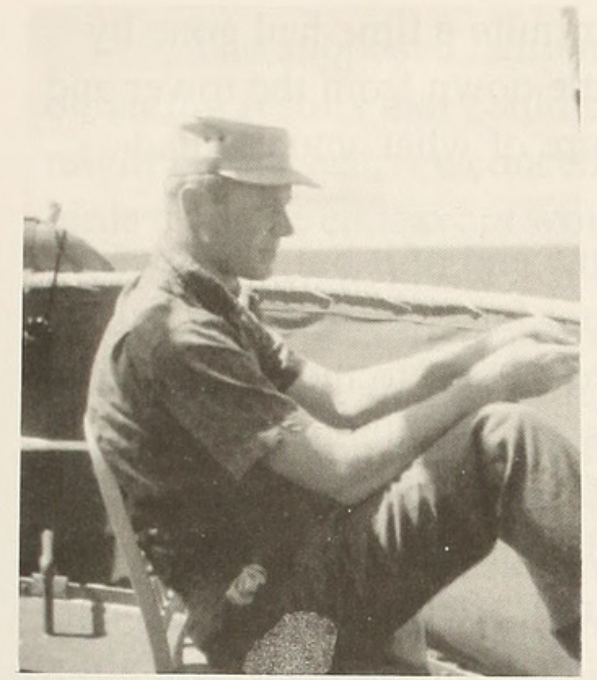

Figure 6. Fred Sibley, exhibiting his usual greenish hue, as he scans the ocean for seabirds.

Some of my colleagues became a good bit more than marginally sick. The late Ralph W. Schrieber, later noted for work on the Brown Pelican (Pelecanus occidentalis)(e.g. Schreiber 1977, 1979), won the Pacific Project prize for our most seasick person. During a trip in 1966 when we were again visiting the "Southern Islands" (Howland, Baker, and the Phoenix and Line Islands), he was so ill that he was barely conscious. One evening on Howland Island, after we had completed our evening chores of banding birds, we walked back to camp to go to bed. Shortly we noticed that Ralph was no longer among us. On a hunch I followed the beach onward from our camp on the west side and finally caught up with Ralph who was walking knee-deep in the water off the south end of the island. I managed to get him turned around and back to camp, but I could never figure out quite what he had in mind. Needless to say, after this voyage Ralph rarely if ever again went on an island cruise and instead concentrated his field work on islands like Christmas Island, Johnston and Wake Atolls to which one could fly.

During the October voyage to the Line, Leeward, Howland and Baker Islands, I encountered my first truly wild areas, rarely and seldom inhabited even by highly adept Polynesians. There were remnants of residence on Howland Island, but this island, with only slight plant growth, was evidently too harsh even for natives who either fled the island or died there. On Howland, I got my chances to census the various boobies and tropicbirds, but an infestation of cats had much reduced any ground nesters and had eliminated them almost entirely from nearby Baker Island. Although not required by our employers, we began a campaign of eliminating cats from this and the other islands where they had become established. They could often be found fishing out on the reef and shot at night, but we found that simply running them down with a large stick in hand was the most effective method. The cats were fleet but lacked stamina and these desert islands gave them few places to hide. After a long pursuit, they would become tired, make higher and higher bounces in the air, and then essentially fall over on their sides allowing their easy dispatch. I had little taste for this activity and left it to others, especially the killing of kittens that we dug out of holes in the guano. Young Larry Huber, however, who was in splendid condition, responded when we pointed out a cat and said "Larry kill" - off he would go to the misfortune of yet another feline.

Howland was also the site of one of my first "adventures" in the Pacific. One night as we were out banding birds as usual, the ship started sounding all its horns, put on all its spotlights, and waved lights around wildly. Needless to say, every bird on the island headed out to sea, pretty much cutting short our work. Fred Sibley, trip leader, got on the radio telephone and learned that we were presumably in the path of an oncoming tidal wave that would arrive so soon that the ship would not have time to retrieve us from the island. We were told to climb to the top of the Amelia Earhardt day beacon (Fig. 7) and tie ourselves together with our belts, which we dutifully did with a 


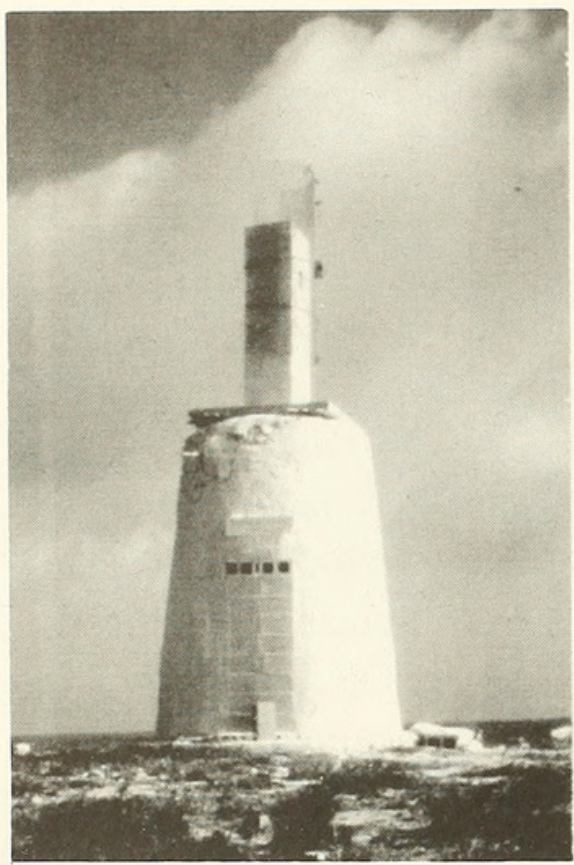

Figure 7. The Amelia Earhardt day beacon on Howland Island, March 1963.

(Photo A. B. Amerson, Jr.) fair degree of anxiety. After quite a time had gone by nothing happened so we came down from the tower and went to sleep, never quite sure of what actually had been going on.

This would have been the end of it but when we went over to Baker Island, not far away, it happened again and once again we tied ourself to the top of a tower, this time the Baker Island Lighthouse, again with no results. We returned to Howland in November and it happened yet again. By this time it was getting to be a bit old hat and, as I was tired, after a short time I climbed down and went to sleep, telling the others not to wake me if I drowned. [Actually, by this time I was pretty sure that the meteorological experts on the ship were really not on their game.] I learned some years later that the water actually did rise during these events, some five feet or so, but because the islands were about 10 feet out of the water, we had been in no real danger.

Landings on the various islands were originally attempted with ships' boats, but the difficulty in landing on some of the small islands was so great that we later used 12-man rubber rafts. Some landings on the coral islands required considerable skill, because cross rips offshore, particularly at treacherous landings such as at Baker Island, often led to rafts capsizing with some hazard to the occupants and loss of valuable equipment. Doug Hackman, for example, once came up under a capsized raft and had a few tough moments before he was able to struggle free. As a consequence of this and other such adventures, one tended to look for the bosun who counted waves. I also made considerable attempts not to be on a raft run by an exmarine whose approach was "Banzai, go, full stream ahead", and who managed to flip boats on a regular basis.

Most of us surveying the islands had our primary backgrounds in ornithology but there were some who had been trained as mammalogists and a few as herpetologists. One of us, Bob Long, was our primary botanist and another, A. Binion Amerson, Jr., specialized in avian ectoparasites (cf., Amerson 1966, 1967, 1968; Amerson and Emerson 1971), but we had few with backgrounds in either botany or invertebrate zoology, surely to our loss. Few of us had Ph.D.s, primarily I suppose because the project was initially envisioned as lasting only 18 months with the result that few established ornithologists wanted to disrupt their employment elsewhere for short-term employment. As a result, many recent college graduates and some with masters' degrees ended up running and doing most of the work in the field, much to their benefit I am sure. On many trips our earlier five-man contingents consisted largely of ornithologists. One trip I remember vividly had three with primarily ornithological interests, one who was more interested in herpetology, and one who was a former jazz musician. 
The supposed temporary nature of our engagement led to problems with obtaining results that could not have been foreseen. Because we thought every trip might be our last, we concentrated primarily on collecting, banding and censusing of birds as these endeavors would seem to produce the most information for the time spent. Little were we to know that the project would run for almost eight years with some areas receiving more than a dozen visits. Consequently, some marking studies that might have revealed considerable information on the various species were never conducted although much information was obtained from our island stations on Kure and Johnston Atolls (cf., Woodward 1972, Amerson and Shelton 1976).

The Pacific Ocean Biological Survey Project (POBSP) was the name under which we conducted our investigations. The older hands, however, remember that its original name, probably because it was essentially based out of the Bird Division of the Smithsonian, was originally the Pacific Ocean Ornithological Project. This name, after someone figured out the acronym, lasted but a short time and we formally buried POOP on Baker Island with appropriate honors.

Lawrence Nicholas Huber, who was my companion on a number of trips to the southern islands and to the Gilbert and Marshall Islands, was one of the most interesting persons I met on the Pacific Program. He had been raised largely by his mother, and, while by no means stupid, retained the naivete of a young child. This led him to engage in actions which led to what were known as the "Huber" stories in which Larry did something untoward and usually with unfortunate results.

I learned of the first of these from his own lips. While in school at the University of Arizona he had been collecting reptiles at which he was quite skilled. As he returned to school, he was pulled over by a state patrolman. I cannot remember why he did not simply tell the officer what he was doing, but I suspect he had animals in his possession that were illegal. To conceal his activities, he had hidden a recently caught, still live Gila Monster (Heloderma suspectum) under his arm. The warmth made the lizard more active, and not liking its captivity much, bit Huber under the arm. Now Gila Monsters are poisonous, if not lethal, and I gather Larry had a hard time of it for awhile.

He added to his reputation no little during the Pacific Program. During our trips to the southern islands onshore we largely ate C-Rations, a diet that led to digestive problems, probably because most had passed their expiration dates, sometimes by nearly a decade. Nonetheless a few items such as pound cake, which was almost edible, became great favorites. Larry managed to annoy the rest of us not inconsiderably by going immediately to the rations and picking out the pound cake before the rest of us had a chance. In retaliation one day, we emptied one of the pound-cake cans, put some stuff in it to get it to the proper weight, left a note inside and sealed it up not too well. Larry, of course, reacted predictably, and the expression on his face when he opened the can to read "Sorry, Booth Food Products" made our efforts well worthwhile.

Larry also had an inordinate fear of sharks, almost a phobia as it was so intense, and often had nightmares about trouble with sharks from which he awoke with considerable distress. It seems safe to say that he actually hated sharks. During the spring of 1964, as we conducted a survey of Palmyra Atoll, low tide allowed many 
small 1-3 ft Black-tipped Sharks (Carcharhinus melanopterus) to cruise near our camp by the lagoon. Larry, seeing a chance to gain vengence on his nemesis, made a small spear and proceeded to happily chase all the small sharks. We watched him with some bemusement as he splashed through the several foot-deep water, but then noticed a somewhat larger fin following him. Somehow, a ca. 8-ft shark was managing to follow Larry as he gave chase to the smaller sharks. We immediately begain yelling and waving to Larry, who initially thought we were cheering him on and who continued chasing the smaller sharks. At one point he glanced over his shoulder, saw the larger shark, and virtually walked on water heading for shore.

During our trip to Marshall and Gilbert Islands in the fall of 1964, a trip ably led by A. Binion Amerson, Jr., we visited various islands, most of them inhabited. The hospitality of the natives was enormous; they usually insisted on roasting a pig on each of our visits. Indeed, one missionary told us our visit was the biggest event in the islands since the visit of Queen Elizabeth. Eventually, the partygoing was cutting significantly into our survey time so two of our members (truthfully, the least able collectors) were appointed the official party people so the rest of us could get on with the survey. This we did, collecting the few bird remaining after the natives had eaten most of the rest. It was clear to us that the natives knew their birds well because they were always pointing out Bristle-thighed Curlews (Numenius tahitiensis) for us to shoot, largely I believe because of their culinary properties. It was also most disconcerting to shoot a White Tern (Gygis alba) or Brown Noddy (Anous stolidus) from the top of the forest, and immediately have some small child come out of the undergrowth carrying it.

During this trip Larry (Fig. 8) was proudly carrying an enormous bowie knife

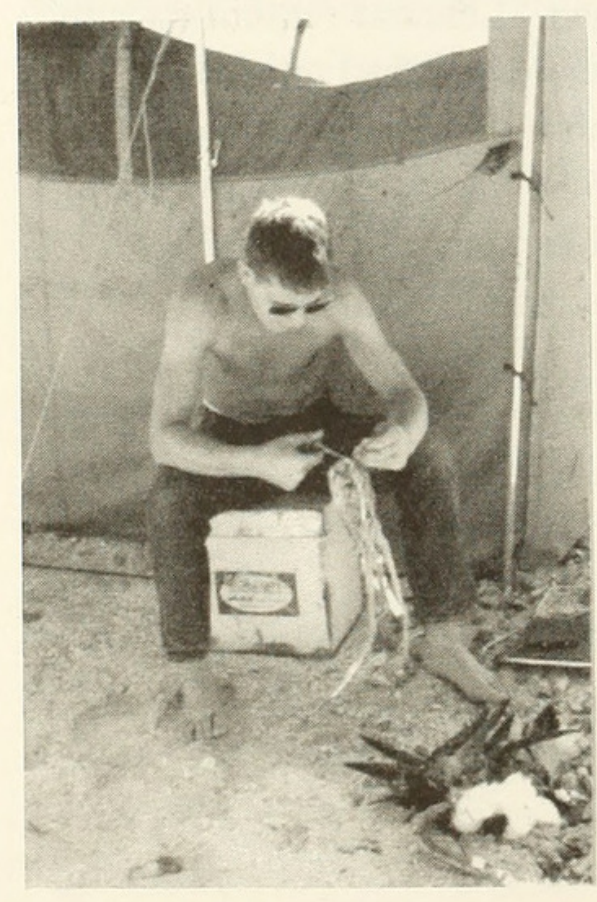

Figure 8. Larry Huber preparing a frigatebird skin in 1964. (for sharks, perhaps?). On one of our first visits to an inhabited island, one of the natives took a sharp stick and with about three rapid strokes dehulled a coconut, opened the shell at one end and offered it to us to drink. Larry evidently envied our admiring comments of the resident's dexterity so he grabbed a coconut, held it against his chest, and proceeded to try to open the coconut with his knife. Predictably, the knife slipped off the coconut and stuck in his chest. Fortunately it managed to hit his breastbone and did little damage, leading once again for the rest of us to remark on his luck.

One of Huber's notions entailed constructing nesting sites for Red-tailed Tropicbirds (Phaethon rubricauda), which always attempt to nest under something, be it an old house as the 10 on Jarvis Island, or under coral rubble along the beach and, at worst, under a heavy tuft of beach grass. Huber made a considerable effort during one trip to implement his idea, actually a good one, by forming shelters in an inverted $\mathrm{V}$ with two slabs of coral rubble. These shelters were immediately and widely used by the tropicbirds and for many years later (Fig. 9). 


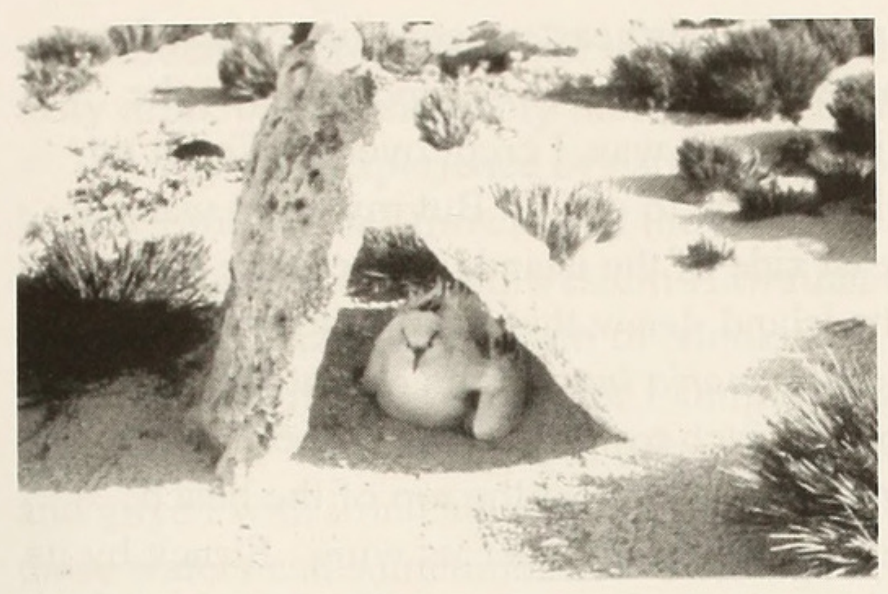

Figure 9. Red-tailed Tropicbird in Huber-built nest site on Jarvis Island in 1972.
My last Pacific Program survey of the Northwestern Hawaiian Islands came in August and September 1967 when I, accompanied by Charles A. Ely, then field director of the Program, and David I. Hoff visited several islands of the chain. It was unique in that our logistic support was three harbor tugs, which accompanied one another, presumably in case one ran into trouble. As a result, Ely and I were on one tug and David Hoff was on another, leaving the remaining one for any unexpected guests. This trip included some of the most extraordinary collecting experiences of my life. Because Ely was unfamiliar with the islands and because he felt he should keep good relations with the crew, I was free to run off to the favored collecting spots, all of which I knew quite well from previous visits. At the overrun area of the airstrip on Sand Island, Midway I collected a Long-toed Stint (Calidris subminuta) on 25 August, on Southeast Island I collected a Ruff (Philomachus pugnax) on 28 August, and on Laysan Island I got two Baird's Sandpipers (Calidris bairdii) on 6 September.

The overrun area on Sand Island, when dry as in November 1980 (Fig. 10), usually holds nothing of interest. Following rain and the presence of small standing pools of water and during the peak of migration in the fall, it is one of the best places in Hawaii to find rare and vagrant shorebirds. Small wonder then that a Semipalmated Plover (Charadrius semipalmatus), previously unrecorded from the Northwestern Hawaiian Islands and the first specimen from Hawaii, and a Lesser Yellowlegs (Tringa flavipes), the second specimen from Hawaii, were also collected there by us in August 1967.

However, the most exciting night of collecting came on Lisianski on 4 September 1967. I had been going to bed somewhat earlier than the others as I had had

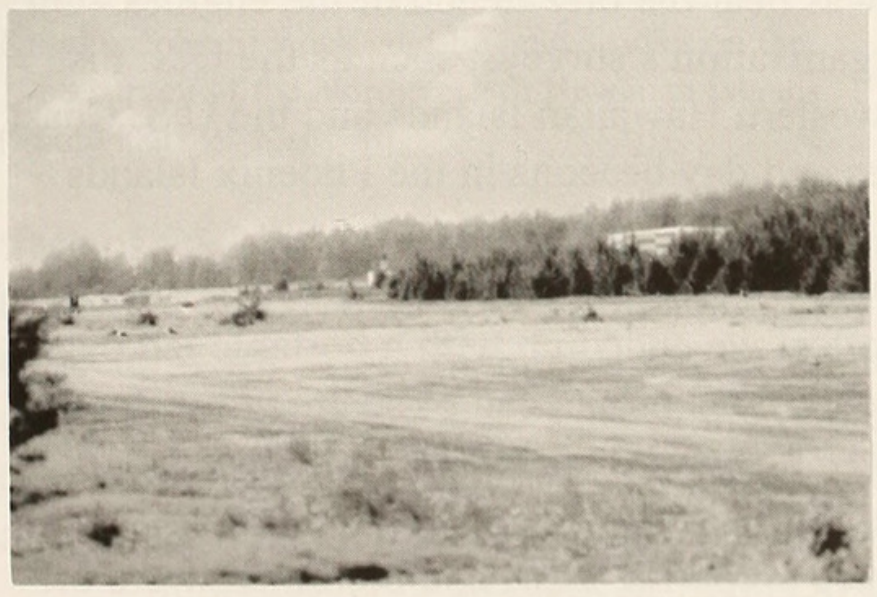

Figure 10. Overrun area at Sand Island, Midway Atoll, November 21, 1980. my fill of banding Sooty Terns in preceding years, somewhat to their disgruntlement. After Chuck, my boss after all, mentioned making more of an effort, I spent most of one night banding birds around the island. As there was no moon I made a special effort to catch Bristle-thighed Curlews in the long grass on the southern portion of the island and was quite successful. Twenty-two years and some months later one of these birds was captured on Laysan Island to become the oldest known example of this species (Marks et al. 1990). 
I continued north along the west shore to the northeastern coastline where I saw a small black petrel sitting among the Bonin Petrels (Pterodroma hypoleuca) in the vegetation along the beach crest. Not knowing what it was, I crept over, picked it up, and dispatched it, putting it in my bag until I got back to camp. But my night was not over. When I was about halfway down the east side of the island, where there is a rocky promontory stretching out somewhat from the island, I saw that the promontory was occupied by many roosting Ruddy Turnstones (Arenaria interpres) and Pacific Golden Plovers (Pluvialis fulva). As I walked down the beach towards them they exhibited their usual wariness, all fleeing to hide among the Scaevola at the top of the beach. However, a single shorebird remained with its head tucked under its wing. Struck by its anomalous behavior, I cautiously approached it, managed to get very close, and reached down and picked it up. It soon joined the petrel in my bag but when I got back to the camp neither Ely nor I knew what the birds were.

Once we got them back to the Smithsonian, it turned out that the petrel was Jouanin's Petrel (Bulweria fallax), a bird from the Arabian sea previously unrecorded in the Pacific (Clapp 1971), and the shorebird was a Mongolian Plover (Charadrius mongolus), the first recorded in the tropical Pacific east of the Marshall Islands (Clapp and Wirtz 1972). The records for Long- toed Stint (Clapp 1968) and Baird's Sandpiper (Woodward and Clapp 1969) were the first acceptable records for the Central Pacific but the Ruff, alas, was only the second specimen for Hawaii (I had collected one earlier on Kure Atoll in December 1963).

Most remarkably this is not the only instance of this petrel, from almost half a world away, occurring in the Northwestern Hawaiian Islands. Fifteen years and 11 months later (4 August 1993), U.S. Fish and Wildlife Service refuge personnel (Seto et al. 1996) found one calling from a burrow in a Bonin Petrel colony at Sand, Midway.

Most of our field work in the central Pacific was done from military vessels with much at-sea work done on the Navy's large YAG vessels. Many of the other surveys were conducted in the much smaller U.S. Army's navy, the ATF series of sea-going tugs. While the YAG's were large and even had staterooms for our use, the A T F's were small and cramped, and we shared bunks down below with the crew, not the most appetizing of places, particularly when one was near the oily stench of the engines. On other occasions we piggybacked on other organization's surveys, such as the U.S. Fish and Wildlife Service's surveys of the Northwestern Hawaiian Islands and the U.S. Coast Guard's annual inspections of the lighthouses and day beacons in the Phoenix Islands and American Samoa.

One of the problems with the ATFs was that we had no space in which to prepare our specimens. After considerable effort we ended up with a portable lab that sat on the fantail with the appearance of an enormous brown can of spam with a door at one end and a long work table along one side. I became acquainted with these labs while preparing specimens with Larry Huber during our cruise to the Gilbert and Marshall Islands. One warm night, as we were preparing skins and the others were off partying, a native arrived with a complimentary drink of fermented coconut milk (better not to ask how this is done). I had a little 6" tumbler from which I sipped as I worked on birds, thinking that the drink was surprisingly mild. What was more surprising was 
my sudden fall from the stool to the lab floor as I sipped on my second tumbler. It was a tasty drink but considerably more potent than I originally thought.

My first experience of participating on another agency's voyage took place in March 1968 when I traveled up the Leeward Hawaiian Chain with Eugene Kridler, the first manager of the Northwestern Hawaiian Islands Refuge, Ernie Kosaka, John Sincock, and Karl W. Kenyon of Monk Seal fame (Fig 11). For some reason my brain was on hold prior to the trip for I simply forgot how unpleasant the trip had been in March 1965. When we got to Nihoa and saw that the Refuge sign way above the water and guyed with iron cables was gone, we were once again reminded of how non-Pacific these waters can sometimes be. Once again, I was freezing daily and were it not for the kindness of John Sincock, who lent me some additional clothes, the trip would have been most unpleasant. The others were primarily interested in surveys of the seals and turtles, but I spent much time once again surveying the seabirds, sometimes stopping to help with the census of endangered species such as the Laysan Teal (Anas laysanensis) and Laysan Finch (Telespiza cantans).

This trip featured the most exhausting collecting experience of my life. I was walking along the northwestern side of the runway at Tern Island, French Frigate Shoals on the warm and sunny afteroon of 14 March when I heard an odd "wicka-wickawicka" call which reminded me somewhat of a Northern Flicker (Colaptes auratus) call.

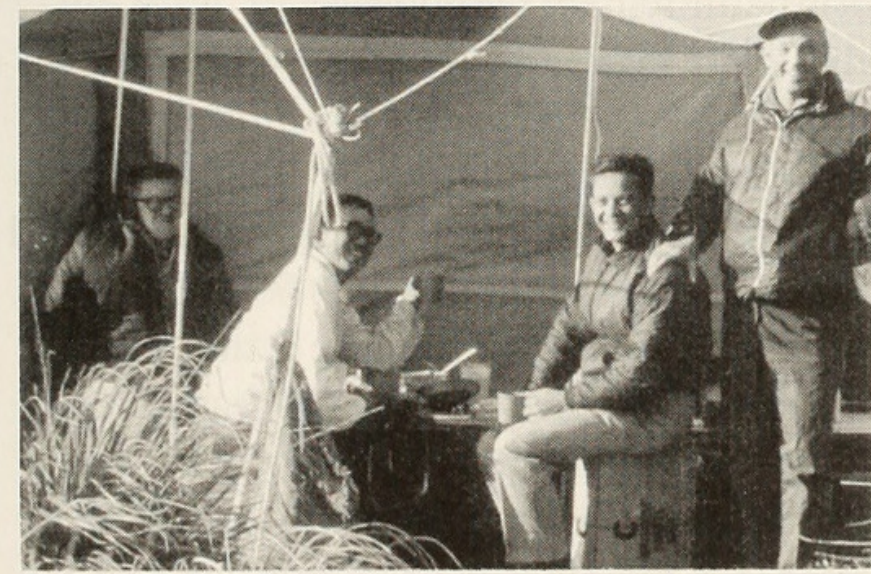

Figure 11. Clapp, thoroughly bundled up, Ernie Kosaka, John Sincock, and Eugene Kridler on the 1968 survey of the Northwestern Hawaiian Islands. (Photo Karl W. Kenyon) As I approached the edge of the runway, I saw a large dark petrel sitting at the edge of a low clump of Scaevola. Unfortunately, it flushed. Knowing that Gene Kridler, as much biologist as preservationist, had brought a shotgun along, I ran most of the rest of the way back to our quarters to borrow the gun. It took me several minutes to catch my breath enough to ask for the gun. Once armed I tried to run back to the spot where I had seen the bird, but was breathing so hard I was reduced at last to a rather staggering walk. To my considerable disappointment, I saw no trace of the bird and was about to leave when I heard the call once again and glanced up to see the bird headed right for me out of the sun. Now while I am a fairly skilled collector, I am a poor flight shot, but I shot anyway. To my surprise and delight the bird dropped almost at my feet. Later, I discovered that the bird was a Herald Petrel (Pterodroma arminjoniana heraldica), an uncommon visitor to North Pacific waters and, at the time, 950 miles north of the previous northernmost record (Amerson 1971). In between our voyages or flights to various islands, we stayed at a hotel in Waikiki and amused ourselves by making surveys of offshore islands, counting and banding birds. It was on one of these visits I had met my once and onetime wife, Tina Abbott, who was then working as an illustrator at the Bernice P. Bishop Museum. On a 
night survey to another islet, Moku Manu, we had to jump from our rafts, swim ashore, and grab a ledge. Although I am a fairly adequate swimmer, I missed the first pass and in the strong swell soon began to founder. Indeed, I was breathing in so much water that I could not even call for help. Fortunately for me, Warren B. King and Robert R. Fleet, both strong swimmers, noticed my plight and jumped back in to undoubtedly save my life. I was enormously grateful, once I finished upchucking a considerable volume of water. This was the third time in my life that I had nearly drowned, leading me to forever be a bit wary of water.

Moku Manu was also the island upon which we found a hybrid between the Blue-faced Booby and the Brown Booby (Sula leucogaster). Although I later caught, banded, and measured this bird, and another that I thought might be a back-cross hybrid, I never got around to formally writing up the record for publication, although the record was of a very rare hybrid, one that then had been only once recorded previously in the Philippines. As is often the case in hybrids between two forms that are not closely related, the hybridization occurred when there were few choices of breeding mates of the proper species. In this case, there was a single pair of Masked Boobies and many pairs of breeding Brown Boobies, while in the Philippines the reverse was true with many breeding Masked Boobies and very few Brown Boobies (Worcester 1911). This bird or another offspring of the mixed pair continued to be seen on Moku Manu for a number of years but I do not know if any hybrids still remain on this islet.

This visit also led me to being somewhat more craven than usual. While Huber and I had arrived and landed safely, when it was time to leave, the surf had risen considerably and I wasn't about to try to swim from the same islet where I had earlier nearly drowned. Consequently, we hid when our pickup boat came which eventually led to a Marine helicopter coming to pick us up. It landed in the middle of a Sooty Tern (Sterna fuscata) colony and the sound of rotors hitting birds sounded like a string of firecrackers popping. The Marines, if not quite panicked, knew this would was not a good situation and departed post haste. I received a few admonitions for this, and the Marines, one of whom said that the landing was scarier than anything he had faced in Vietnam, wanted nothing to do with us thereafter. On the other hand, I didn't drown.

One aspect of our work on the islands was the mass banding of enormous numbers of seabirds. Most of this was done at night with headlamps that provided an eerie sight as a line of bobbing lights proceeded through the darkness. Dark of the moon was the best time of course, and full moon the worst because many birds would flush if they could see to fly.

Most of the birds we banded were fairly small and relatively easy to handle, but the Blue- faced Booby (now known as Masked Booby), was another matter. The size of a small goose with a 5" bill (Fig. 12) with fish-knife serrations along the edge and a clamp like a vice grip, this booby was one that one grabbed with some care. The females, larger than the males and with a less yellow bill during the breeding season (Fig. 13), were more dangerous than the males but either could give you a nasty bite. Usually one would distract a bird with one hand, grab it by the neck with another, sling it between one's legs with the head to the rear, and pull up the leg to attach the band. The release was also done with some care because a mistake could leave an unpleasant 
grip on the leg and perhaps elsewhere.

I am happy to say that in handling thousands of these boobies, I never made a really bad release, but Fred was less lucky. During one night of banding the significantly smaller Red- footed Boobies, which have particularly agile necks, he was grabbed in a sensitive area as we could all tell from the noise coming from his direction.

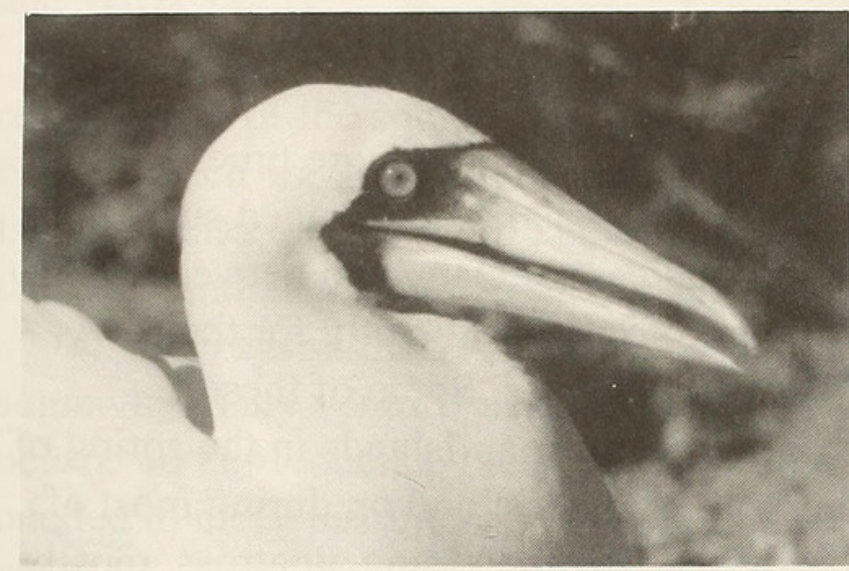

Figure 12. Dangerous end of large female Masked Booby, Christmas Island. April 15, 1988.

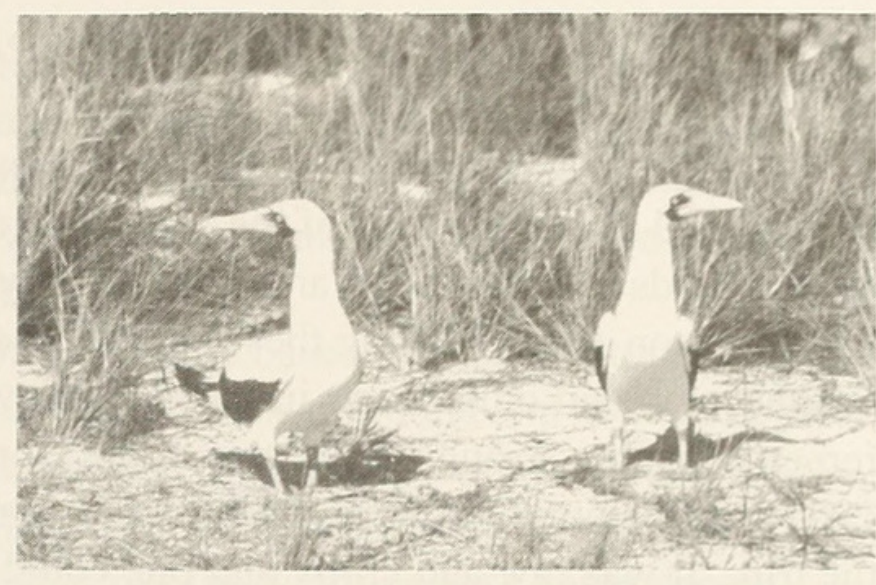

Figure 13. Pair of Masked Boobies on Christmas Island. April 21, 1988; the smaller male is on the right.

This is the first, and last, time I ever saw a Red-footed Booby dropkicked (and so far!), but Fred apparently recovered all right as he has a number of offspring.

The Masked Booby strike is very fast, however, and I learned how to capture them the hard way during my first visit to the Phoenix and Line Islands. By the time the two months of field work were completed, I had five major infections on one hand, four on the other, and my hands were swollen so badly that they flew me back from Canton, rather than let them fester during the six or seven days it would take to return to Honolulu. Other species caused little damage but could be seriously annoying, the worst of which were the Wedge-tailed Shearwaters (Puffinus pacificus). They continually battled the bander, trying to bite and claw so vigorously that one needed a glove with a gauntlet on one hand to keep one's wrist from turning red with scratches. This degree of aggressive behavior was characteristic of the Wedge-tailed Shearwater alone; other petrels such at the Christmas Shearwater (Fig. 14) were relatively docile and made little

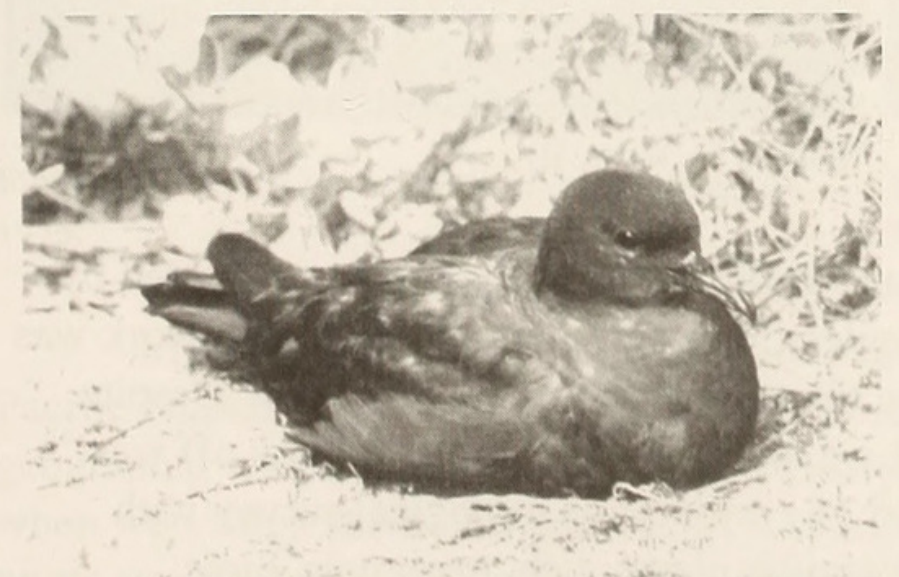

Figure 14. Christmas Shearwater on Motu Upua Islet, Christmas Island. April 21, 1988. fuss. Indeed, the White-throated StormPetrels (Nesofregetta fuliginosa) were so tame that they would sit unrestrained on your hand for a number of moments before deciding to take flight.

Because much of the banding activity was pretty much repetitive drudgery, stoop labor for the Pacific, we often made a contest out of who could band the most birds. One evening on Jarvis Island, I won the all-time [Masked] Booby grabbing competition 
with a total of 566 to Fred's 560 with Larry trailing badly at 300 or so. I must admit, had I not run into this enormous club (roosting aggregation) where I banded more than 100 birds (some later found nearly 1,000 miles away on Howland Island), I would not have won as Fred was really more adept than I.

\section{POST PROGRAM PACIFIC PEREGRINATIONS}

In ensuing years I visited the Phoenix and Line Islands three more times, participated in two surveys of the Northwestern Hawaiian Islands, and joined surveys of pelagic birds in a variety of areas, but mostly north and east of Oahu and between Oahu and Johnston Atoll. During these years some of our touring was directly for the Smithsonian and other times in conjunction with other agencies. Some of these I remember more strongly. The trip to the Northwestern Hawaiian Islands in the spring of 1965 was memorable for the truly rotten weather as it rained off and on during most of the trip. It was raw and chilly and one could easily see why the young albatross, mostly birds of southern ocean islands, needed their dense plumage. We had to go out and reshore up our tents following many a windy and rainy night (Fig. 15), during one of which a tent finally collapsed drenching those within. During the day, much of our work as usual entailed banding and censusing birds (Fig. 16) and censusing Hawaiian Monk Seals (Monachus schauinslandii) and Green Turtles (Chelonia japonica) as well.

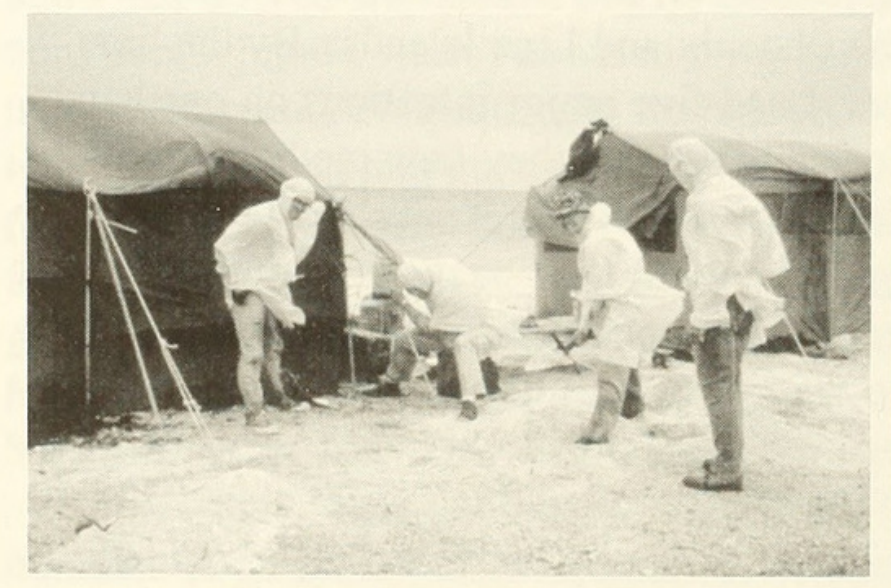

Figure 15. Setting up camp on Southeast Island, Pearl and Hermes Reef, March 1965. (Photo William O. Wirtz, II)

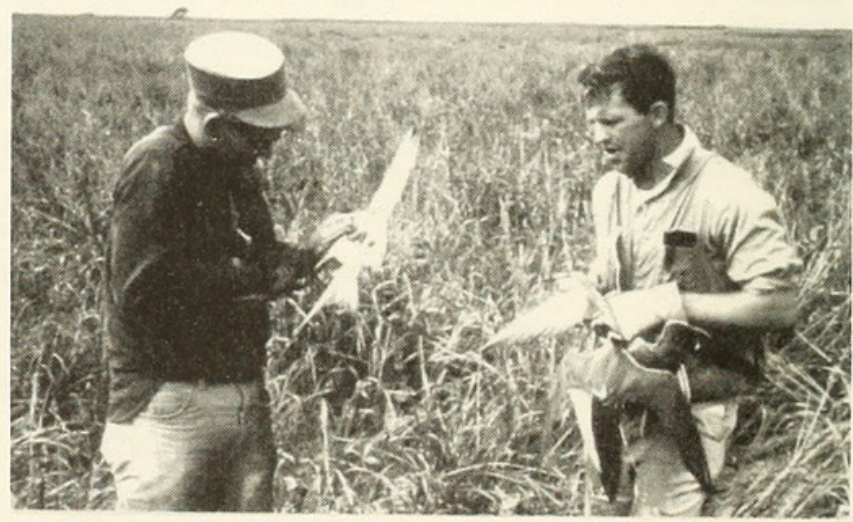

Figure 16. Clapp and Dennis Stadel banding Graybacked Terns (Sterna lunata), on Lisianski Island, Northwestern Hawaiian Islands, March 1965. (Photo William O. Wirtz, II)

Some have criticized the Smithsonian Pacific Project because it was funded by the military and because we took blood samples from the birds (although such work was being done quite openly at the same time on the eastern shore of Maryland). Despite the occasional cloak of "secrecy", little that we did (and nothing that I know of) was certainly secret. Most of our work consisted of a wide-scale biological survey with attempts to obtain representive samples of vascular plants, fish, mammals, birds, reptiles, insects and other arthropods. 
Following the Pacific Project, I accepted a job in the fall of 1970 with the U.S. Fish and Wildlife Service's Bird and Mammal Laboratory and spent much time curating the North American bird collection. I was also allowed to spend one day a week in completing a number of overview Atoll Research Bulletins on the fauna and flora of the Northwestern Hawaiian Islands (e.g. Ely and Clapp 1973, Amerson et al. 1974, Clapp and Wirtz 1975).

Field work, to my disappointment, became much more limited but I manage to revisit some of the southern islands in 1970 and 1971 as a consultant to the U.S. Air Force, which wanted to put some towers on these islands to track ballistic missile launches into Canton Atoll lagoon. My last visits to the southern islands were during the 1973 and 1975 joint Anglo/Smithsonian Expeditions.

Surveys in the 1970s were by helicopter from the base camp on Canton Atoll, a somewhat risky venture as some of the trips entailed a 500- mi round trip over the open ocean. In consequence the helicopters went in groups of three although only one was needed to carry passengers. I got in the habit of sitting near the door with a seat belt extending from the seat. This allowed me to lean out the door and take some decent aerial photographs of some of the islands (Figures 17, 18). During one of these surveys, the helicopter heeled over in a downdraft leaving me at a sort of 45-degree angle to the ground. I absentmindedly put one hand on the top of the door to stable myself while continuing to take photographs. When the helicopter leveled, I looked down and saw that I had completely stepped out of the seat belt meaning that only my fingertips had kept me from a sudden drop of ca. 500 feet to the ground. I quietly sat down, sweating considerably although it wasn't that hot, hoping that none had noticed. Unfortunately one of the crew had and they never let me near the door again.

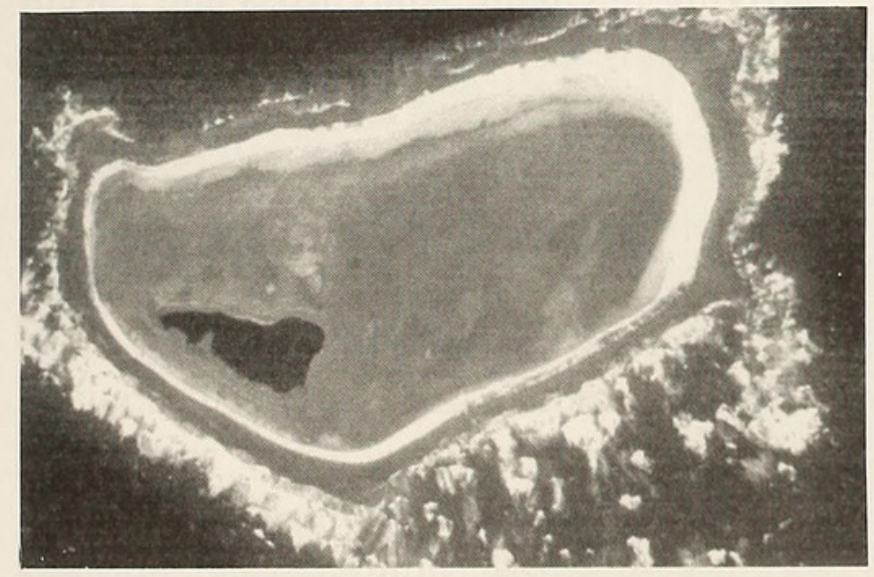

Figure 17. Aerial view of Birnie Island. May 30, 1973.

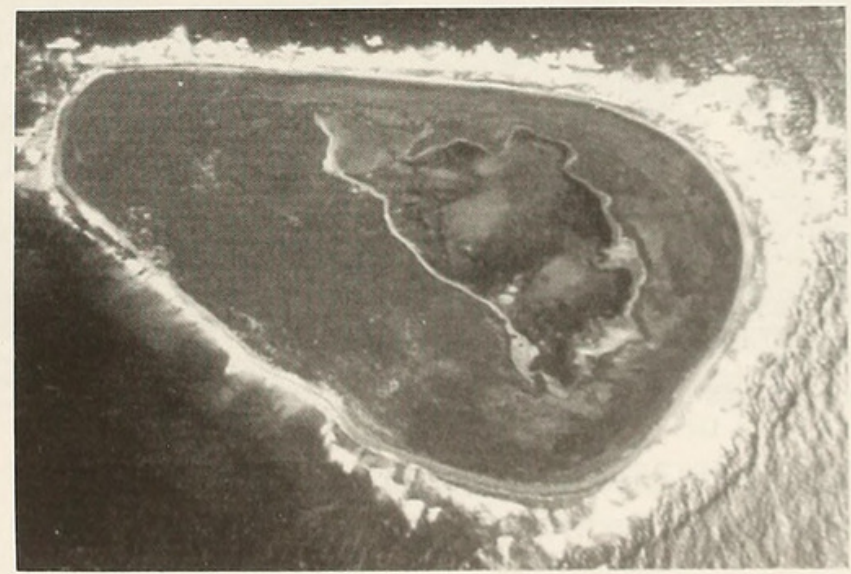

Figure 18. Aerial view of Phoenix Island. June 2, 1973.

My companions in 1975 were Ray Fosberg, whose encyclopedic knowledge of Pacific Islands was ever a source of inspiration, and David Stoddard, a British geographer who was both energetic and enterprising. I was considerably embarrassed when we visited Birnie Island which I had noted had but three species of vascular plants on its small surface (so small, in fact, that the Wilkes Expediton passed it up for nearby Enderbury Island seen in the distance.). Ray and David immediately walked almost 
directly to a withered bush of Sida fallax which I had never seen on the island. I consoled myself that this was after the long drought that had occurred during the days of the Pacific Project and it could have easily been overlooked.

During the summer of 1978 I accompanied Elizabeth Cummings, then an assistant refuge manager, on another U. S. Fish and Wildlife Service survey of the Northwestern Hawaiian Islands - my only visit there at that season (Fig. 19). I ended up being a tourist guide for Liz (who is now my neighbor in Aldie, Virginia), but still managed a few observations of interest. During July, when the last of the Laysan (Diomedea immutatilis) and Black-footed (Diomedea nigripes) Albatrosses were fledging, the offshore waters filled with Tiger Sharks (Galeocerdo cuvier) that gathered to feed on uncautious young. One young Black-footed Albatross was particularly unfortunate. It apparently had a defect in its barbules making its feathers completely unable to support flight. Day-by-day it stood there, slowly starving to death, but I guess it eventually decided on suicide. I watched as it walked to the edge of the water, swam a few hundred yards out to sea, and was engulfed by a huge maw coming up from below, the tips of its wings being the last seen as the bird was dragged below.

Further field work in the Pacific occurred during the fall of 1979 when I organized an expedition to the northern Mariana Islands. The 1979 trip produced perhaps the greatest gaffe of my career. I had to spend many nights prior to the Marianas trip arranging for a yacht, the "Lion's Den," to take us up the chain and spent daylight hours doing my regular work. In consequence, when we arrived in the

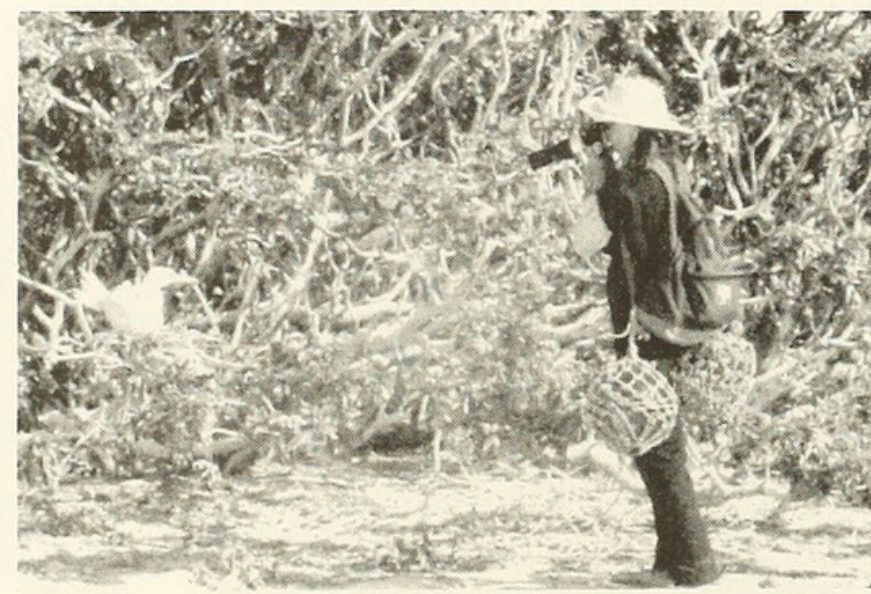

Figure 19. Liz Cummings making the acquaintance of a nesting Red-footed Booby (Sula sula).
Marianas I had no time to familiarize myself with the specimens of the species that we might encounter. One day after arriving in Guam, Andy Ross and I went up to the reservoir to

collect birds. To my amazement a large thrasher-like bird, which I did not know, flew up and began singing. Having recently read a paper by Ricklefs explaining why high altitudes were likely to produce new species, I thought that I had indeed found a new species and promptly collected the bird.

During the ensuing trip I mentioned it to the skipper who had previously told me he was happy to be one of the first (if not the first) to take a yacht into the Northern Marianas during the typhoon season (which was news to me). He included this "fact" in an article he later wrote for a local magazine. On our return to Guam, we once again went out collecting near the former Japanese airstrip at the northern end of the island. A bird with an unfamiliar silhouette popped up on a branch nearby, and with my reflexive collector's instinct, it was immediately shot. When I walked over to pick it up, I realized it was the same species that I had shot near the reservoir about a month ago. Two and two suddenly came together and I instantly realized that I had not one, but two, examples of the endangered 
Nightingale Reed Warbler (Acrocephalus luscinia).

I immediately realized that I was in some trouble, particularly since I had already retrieved an endangered Micronesian Megapode (Megapodius laperouse), that had stumbled into a rattrap that Andy had set on Guguan. I did know this bird was endangered and dutifully released the chick from the trap whereupon it walked in a circle and fell on its side. I picked it up and set it upright and it did it once again. After several more repetitions of this behavior, I realized that it had become so badly damaged that it could not possibly survive and took it as a specimen considering that its value as a specimen was more important than the fact of my collecting it. On our return to Honolulu, I immediately called Ernie Kosaka who arranged for an agent to come over and pick up the specimens. Later, back in Washington, I received some hard- nosed interrogation by enforcement officials, but I managed to convince them that I was only an idiot and not a conscious malefactor.

Although we obtained a good series of small-bird specimens for the museum, relatively little was published based on this trip other than our discovery of a considerable range extension for the Gray-backed Tern (Sterna lunata) (Clapp and Hatch 1986) and the inclusion of some of our records in a paper reporting new distributional records for the Northern Mariana Islands (Glass et al. 1990).

The trip itself was not uneventful although the quarters where we recorded data and prepared specimens were quite cramped (Fig. 20). Most of the islands, volcanic peaks rising out of the sea, had poor or no anchorages leading to keeping a wary eye on weather conditions. At some stops, Danny the bosun or someone else actually dived to find some kind of fixed rock or ledge to which to attach the anchor, but often the boat just floated offshore while we conducted surveys on the islands. One day, as I sat on the

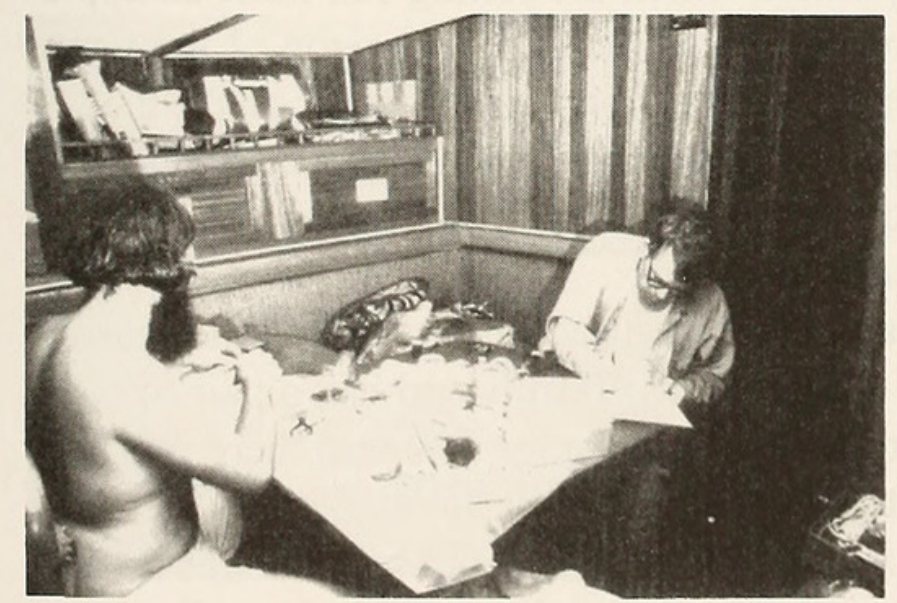

Figure 20. Andrew Ross and Clapp at work in the chartered yacht fantail and Andy worked on herpetological specimens, an enormous green wave came rolling in and, although the yacht was well away from the island, we were being pulled up and driven towards the cliff. The captain called down to the bosun for "full astern" only to hear the reply "you know we don't have any astern". While sitting there wondering how long I had, and whether I would survive jumping off the back of the boat, the captain with considerable presence of mind called for "full ahead" which fortunately was

available. The captain pulled the boat in a circle as it slid toward the cliffs and we came close enough so that I could have hit the Black Noddies (Anous minutus) roosting there with a rock.

Although I was no longer primarily working on seabirds, I continued to do a fair amount of work on marine birds elsewhere. During the early 1970s, my skills as a rapid bander of seabirds were enlisted by John S. Weske to help him in banding creches of 
Royal Terns (Sterna maxima) on the eastern shore of Virginia and North Carolina (Fig. 21).

My last voyage to the Northwestern Hawaiian Islands occurred in November 1980 under the auspices of the U.S. Fish and Wildlife Service. I was accompanied by Nancy Withers, who was interested in nudibranchs, her assistent Deborah Burns, and Eric (whose last name I have forgotten), whose job was to collect seal skat (Fig. 22). My companions were most pleasant and introduced me early in the trip to the "green

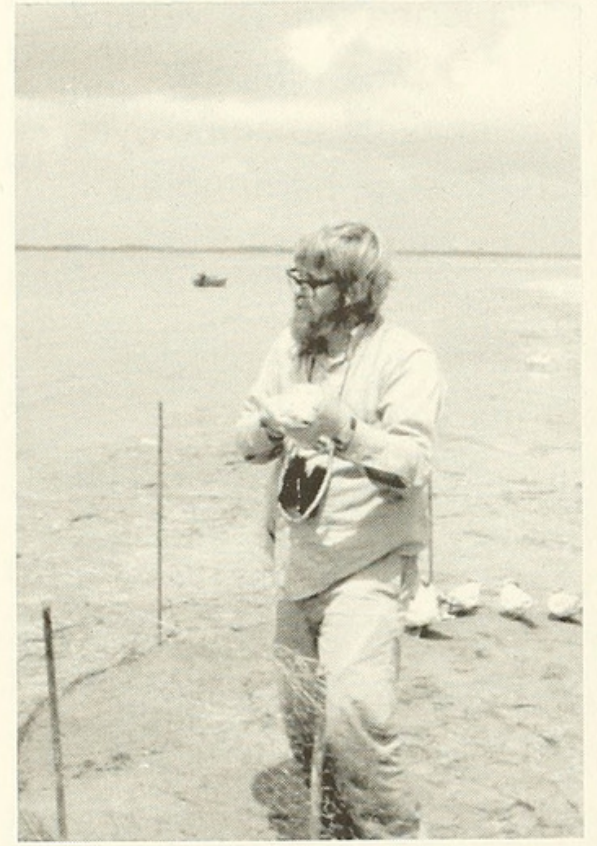

Figure 21. Banding Royal Terns on Fisherman's Island, August 19, 1973.

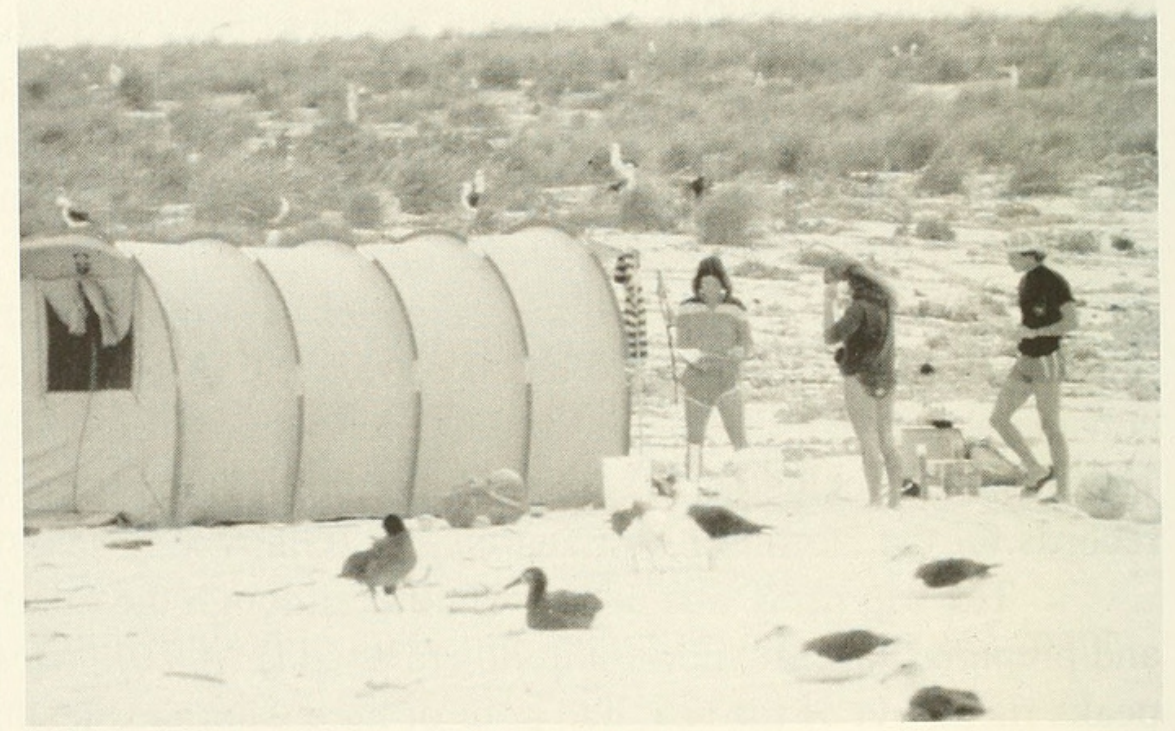

Figure 22. Camp on Laysan Island. November 16, 1980, Nancy, Deb, and Eric, near entrance.

flash," the point at which the setting sun turns an apple green just before it slips below the horizon. Like many others, I thought this was some strange legend, so I was nonplused when I saw it the very first night that my very much more experienced companions had predicted its occurrence. I was much pleased a number of years later to see a color photograph of this phenomenon on the cover of Scientific American.

On this trip I carried no armament but a camera. It was pretty late in the season though, so not many vagrants were present. Nonetheless, Tern Island had a pair of Mallards (Anas platyrhynchos) that had become relatively tame. Because there was virtually no standing fresh water, they took to using a child's plastic wading pool as their choice for a swimming area (Fig. 23). Another uncommon bird present was a Cattle Egret (Bubulcus ibis), presumably from the population in the main Hawaiian Islands, not so tame as the Mallards, but still allowing a fairly close approach (Fig. 24).

Not surprisingly, once we got to Midway I headed for the overrun to find it dry to my great disappointment (See Fig. 10 above). While we were on Sand Island, someone told us, though, that there were ducks in the island reservoirs. With Eric's help we went to the reservoir and managed to obtained some vagrant ducks. (At that time the Navy was not as negative about shooting as was the U.S. Fish and Wildlife Service). Eric's role was gradually to shoo the ducks towards a wall of the reservoir so we could use a long dip net to retrieve them. We ignored the various Northern Pintails (Anas 


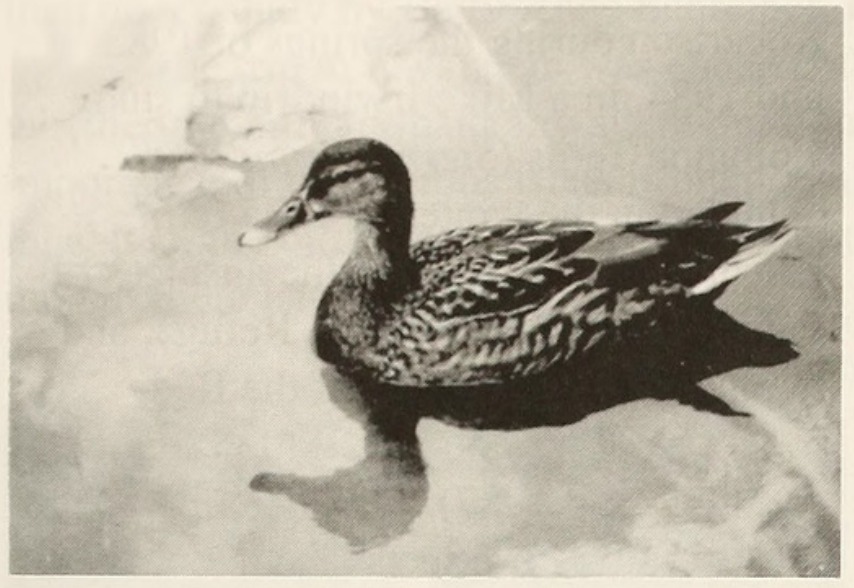

Figure 23. Female Mallard in wading pool on Tern Island, French Frigate Shoals. November 10, 1980.

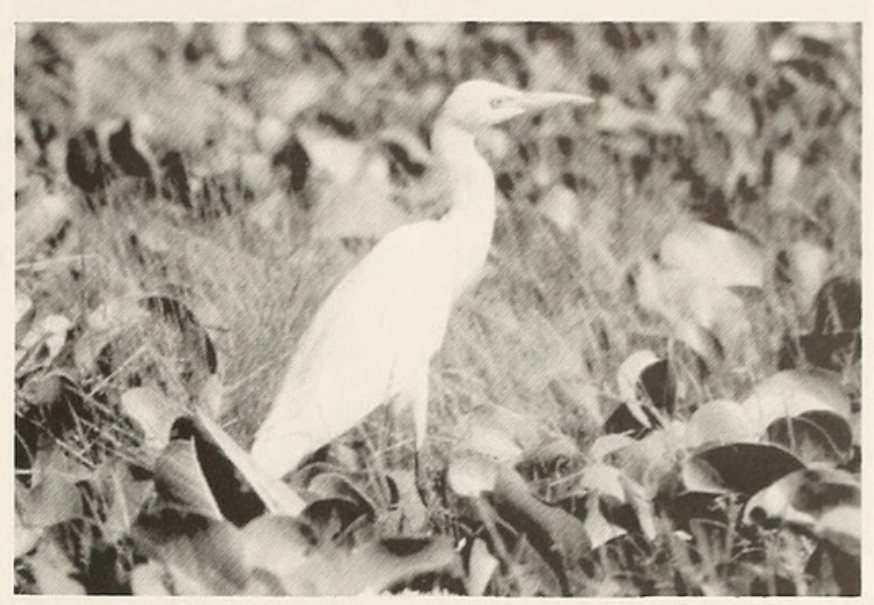

Figure 24. Cattle Egret among the morning glories, Tern Island, French Frigate Shoals.

acuta), regular in the Northwestern Hawaiian Islands and by far the most common migrant duck there. We instead obtained on 22 November a fine adult male Bufflehead (Bucephala clangula, USNM 599951), a female and male Tufted Duck (Aythya fuligula, USNM 599952, 599953), perhaps the second most frequent migrant duck at Midway, and a male Black Scoter (Melanitta nigra, USMN 599954), the first record of that species from Hawaii and the tropical Pacific (Fig. 25).

The previous day I had made my first acquantance with an adult Short-tailed Albatross (Diomedea albatrus), a species that usually lives on Torishima Island near Japan. Because it bore a band, I thought it worthwhile to catch the bird and send the band number to the banding office at Patuxent Wildlife Research Center. The Blackfooted and Laysan Albatrosses have a relatively slow strike and I had previously

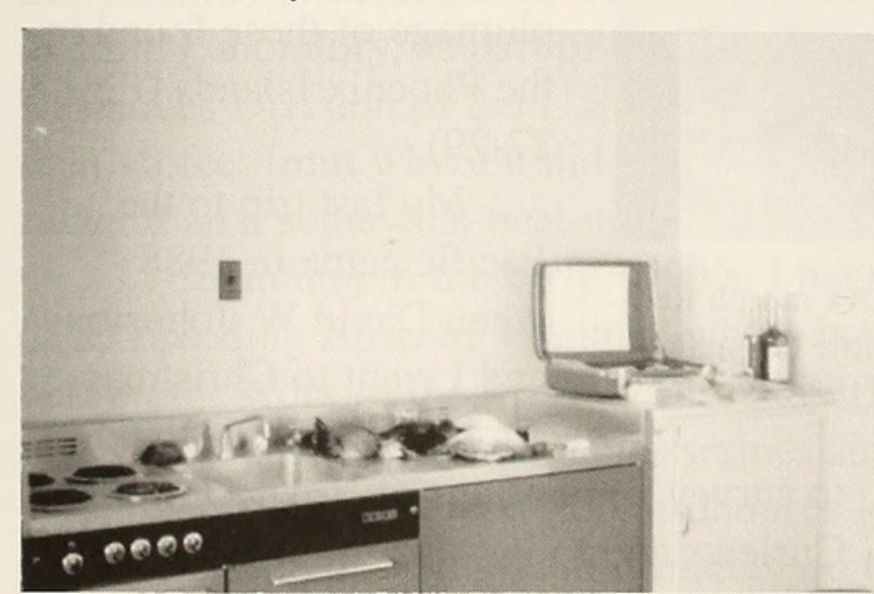

Figure 25. Room at the Bachelors' Officer Quarters (BOQ) with the catch of the day. November 22, 1980. captured hundreds, if not thousands, of them with a slow grab to the neck. I tried the same on the Short-tailed Albatross, but forgot that it is much larger than the other two (Fig. 26). Although my grab was eminently successful, the Short-tail, because of its longer neck, had no difficulty reaching back and ripping the top of my arm with the hook of its bill. The resulting wound was spectacular, if superficial, and a sheet of blood poured off my arm. After reading the band, I released the biid and at the insistence of others went to the

nurse's office to get my really very minor wound treated.

During the latter part of the 1970's and early 1980's, I spent much time compiling three large treatises on marine birds of the southeastern United States and Gulf of Mexico (Clapp et al. 1982a, 1982b, 1983)) and also aided in a compilation dealing with waterbirds of the New York Bight (Howe et al. 1979). I also participated 


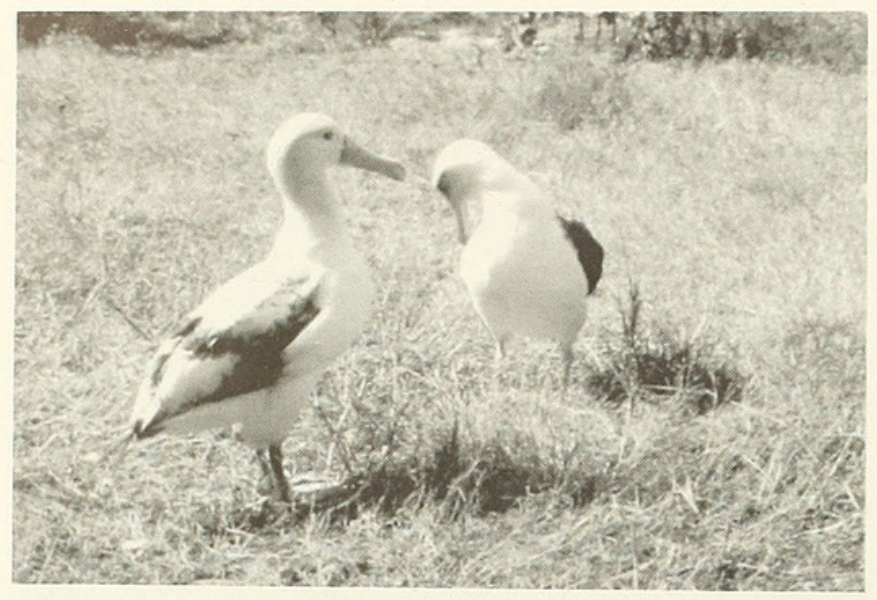

Figure 26. Short-tailed Albatross (left) and much smaller Laysan Albatross (right) on Sand Island, Midway Atoll. November 21, 1980.

in work on Sooty Terns with Bill Robertson during the springs of 1983 and 1984, in a Mike Irwin trip to study Common Terns (Sterna hirundo) in Trinidad in the winter of 1985 (c.f. Erwin et al. 1986) under the auspices of Patuxent National Wildlife Refuge, and in a winter 1986 survey of the Redfooted Booby colony on Little Cayman Island (Clapp 1987). The latter entailed mostly cutting transects through heavy vegetation to census the boobies. This was not without hazard as there were points of eroded limestone sticking up like needles in depressons

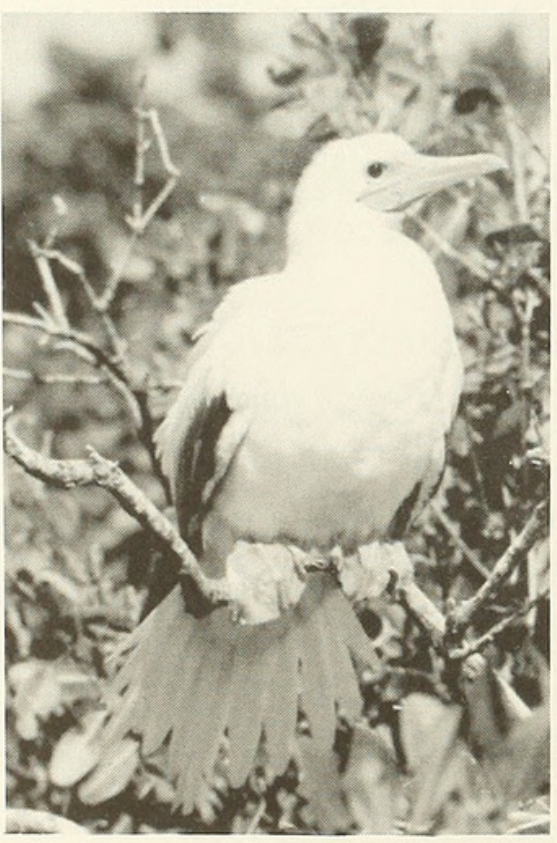

Figure 27. Adult white morph Red-footed Booby on Little Cayman Island. January 26, 1986.

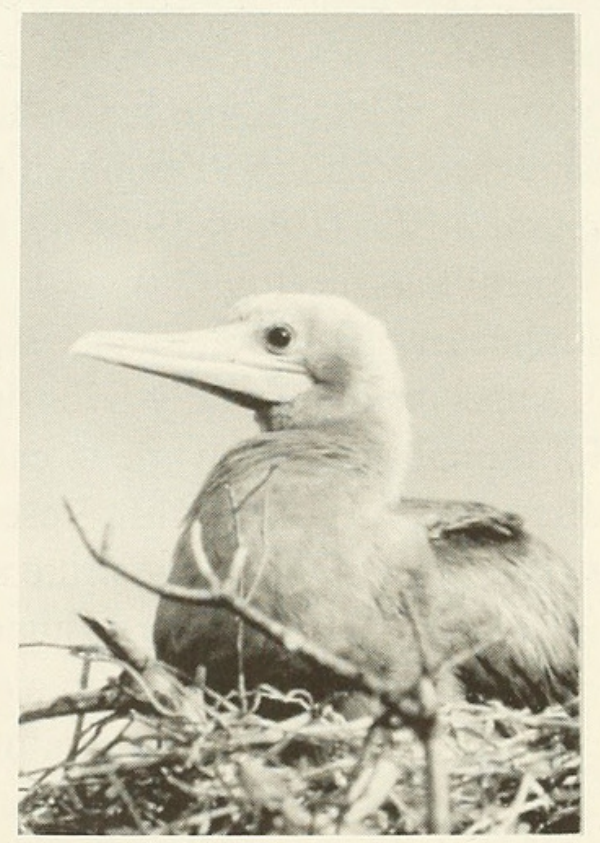

Figure 28. Adult dark morph Redfooted Booby on Little Cayman Island. January 23, 1986. among the nesting trees, but I fortunately remained unpunctured despite a few close calls. The Redfooted Boobies here come in color phases like those in the tropical Pacific and the Northwestern Hawaiian Islands, but none have the variegated plumage of those found in the Phoenix Islands (Figs. 27-29).

My last trip to the Pacific came in 1988 when David W. Johnston and I went to Christmas Atoll in the Line Islands

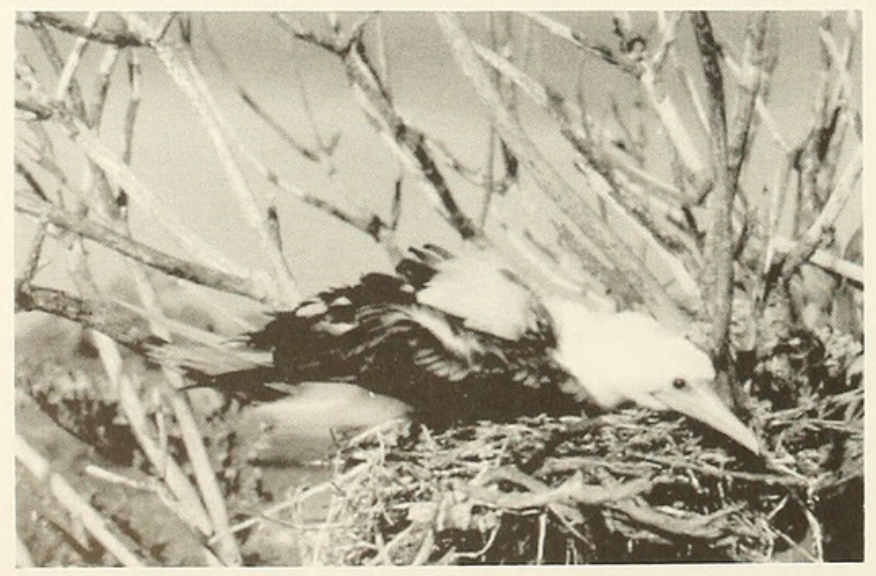

Figure 29. Adult variegated Red-footed Booby on Christmas Island. April 18, 1988. to survey populations of Bristle-thighed Curlews and to Kwajalein Atoll to make a survey of the ornithological resources there. The trip to Christmas Atoll was pretty much of a bust as only a few shorebirds remained there, most having already migrated north. I did enjoy my week there, though, obtaining a considerable number of pictures of the breeding seabirds as well as doing some surveys and banding (Fig. 30) in areas 
then under study by Betty Anne Schreiber, Ralph Schreiber's widow.

The trip to Kwajalein was considerably more successful (Clapp 1990), although whether the military paid any attention to my comments on the ornithological importance of the various islets is unknown to me. Because the atoll has long been inhabited, the bird life is fairly sparse but occasional colonies remain on some of the more remote islands (Fig 31).

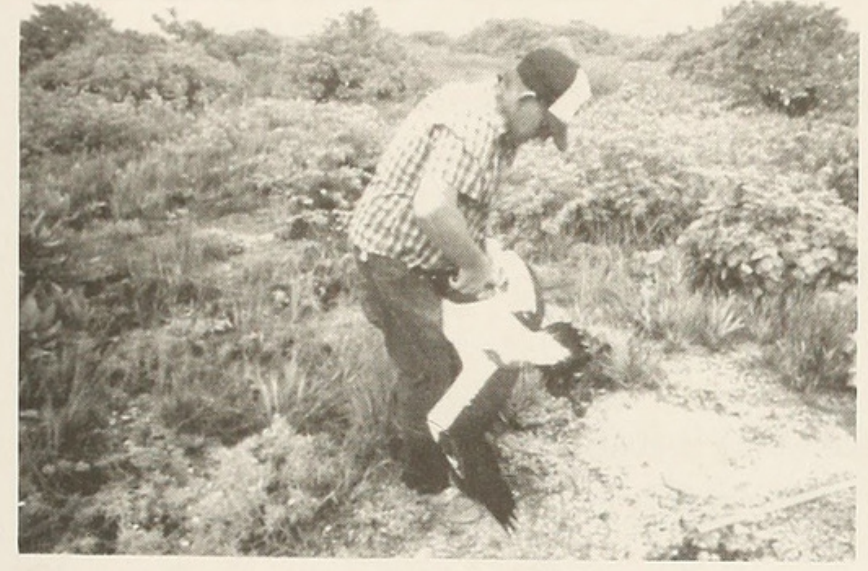

Figure 30. Banding a Masked Booby on Christmas Atoll. (Photo David W. Johnston)

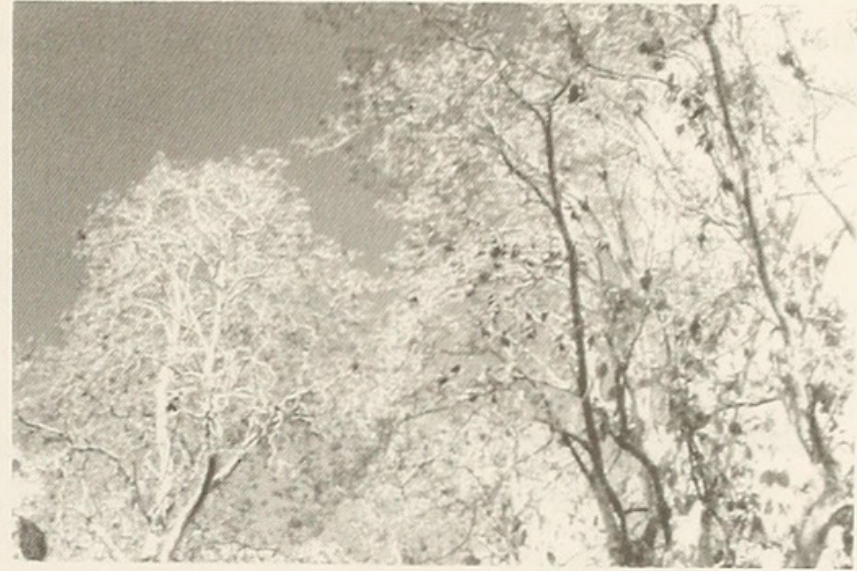

Figure 31. Black Noddy (Anous minutus) colony on Enewetak Islet, Kwajalein Atoll. March 16, 1988.

\section{RECENT YEARS}

Over the years I have continued to work for the same organization at the Smithsonian through a number of title changes and affiliations (e.g. National Fish and Wildife Laboratory, as part of the Biological Survey, and now as part of the Biological Resources Division of the U.S. GeologicalSurvey). Nonetheless, my desk stands less than 10 feet from where it did nearly 40years ago, although it now has two computers rather than a somewhat beat-up typewriter.

Beginning in the early 1990's, I began working as senior editor of a book on "The Breeding Birds of Virginia" which is to include maps of bird distribution based in part on the work of the Virginia Bird Atlas Project 1984-1989. Consequently, much of my work has been focused on passerines since then. During this period I have gradually assembled a string of over 800 birdhouses located in five northern Virginia counties and have amassed considerable information on the breeding biology of various species, much of which is being used in species accounts being prepared by myself and others. Despite my interest in this project, I still remember my years in the Pacific as the high point of my career, and only wish I could visit them once again.

While Central Pacific ornithology has produced much good material since the heydays of the Pacific Project, it seems unfortunate that the great mass of anecdotal and banding data from those years still, and perhaps forever, will remain unanalyzed. Some species-specific information has been summarized for the albatross (Sanger 1974a, 1974b), Wedge-tailed Shearwater (Puffinus pacificus) (King 1974), storm-petrels (Crossin 1974), Red-tailed Tropicbird (Gould et al. 1974), Sooty Tern (Gould 1974), 
Blue-gray Noddy (Procelsterna cerulea (Rauzon et al. 1986) and the Gray-backed Tern (Mostello, et al., 2000) that incorporates data from the various islands studied, but most of these studies deal more with pelagic observations than those made on land. There still remains a great deal of information on the natural history, populations, distribution and movements of other species that remains unsynthesized. Four of the southern islands, Howland, Baker, and Jarvis Islands, and Palmyra Atoll, are now National Wildlife Refuges, the last designated quite recently. The Fish and Wildlife Service and I made post- Project visits to these islands and the data on these islands should be summarized for the benefit of future generations.

\section{REFERENCES}

Amerson, A. B., Jr.

1966. Ornithodoros capensis (Acarina: Argasidae) infesting Sooty Tern (Sterna fuscata) nasal cavities. Journal of Parasitolology 52(6):1220-1221.

Amerson, A. B., Jr.

1967. Incidence and transfer of Rhinonyssidae (Acarina: Mesostigmata) in Sooty Terns (Sterna fuscata). Journal of Medical Entomolology 4(2):197-199. Amerson, A. B., Jr.

1968. Tick distribution in the central Pacific as influenced by seabird movement. Journal of Medical Entomology 5(3):332-339.

Amerson, A. B., Jr.

1971. The natural history of French Frigate Shoals, Northwestern Hawaiian Islands. Atoll Research Bulletin 150. xv \& 383 pp.

Amerson, A. B., Jr., R. B. Clapp, and W. O. Wirtz, II

1974. The natural history of Pearl and Hermes Reef, Northwestern Hawaiian Islands. Atoll Research Bulletin 174. xiv \& 306 pp.

Amerson, A. B., Jr., and P. C. Shelton

1976. The natural history of Johnston Atoll, Central Pacific Ocean. Atoll Research Bulletin 192. xix \& 479 pp.

Amerson, A. B., Jr., and K. C. Emerson

1971. Records of mallophaga from Pacific birds. Atoll Research Bulletin 146.30 pp. Clapp, R. B.

1968. Three unusual shorebirds from Midway Atoll, Pacific Ocean. 'Elepaio 28(9):76-77.

Clapp, R. B.

1971. A specimen of Jouanin's Petrel from Lisianski Island, Northwestern Hawaiian Islands. Condor 73(4):490.

Clapp, R. B.

1987. Status of the Red-footed Booby colony on Little Cayman Island. Atoll Clapp, R. B. Research Bulletin 304. 15 pp.

1990. Notes on the birds of Kwajalein Atoll, Marshall Islands. Atoll Research Bulletin 342. $94 \mathrm{pp}$. 
Clapp, R. B., R. C. Banks, D. Morgan-Jacobs, and W. A. Hoffman

1982b. Marine Birds of the Southeastern United States and Gulf of Mexico. Part I. Gaviiformes through Pelecaniformes. U.S. Fish and Wildlife Service, Office of Biological Services, Washington, D.C. FWS/0BS-82.-1. xi \& 637 pp.

Clapp, R. B., and J. Hatch

1986. Range extension for the Gray-backed Tern in the western Pacific. Colonial Waterbirds 9(1):113-116.

Clapp, R. B., E. Kridler, and R. R. Fleet

1977. The natural history of Nihoa Island, Northwestern Hawaiian Islands. Atoll Research Bulletin 207. v \& 147 pp.

Clapp, R. B., D. Morgan-Jacobs, and R. C. Banks

1982a. Marine Birds of the Southeastern United States and Gulf of Mexico. Part II. Anseriformes. U.S. Fish and Wildlife Service, Office of Biological Services, Washington, D.C. FWS/0B5-82-20. xiii \& 492 pp.

Clapp, R. B., D. Morgan-Jacobs, and R. C. Banks

1983. Marine Birds of the Southeastern United States and Gulf of Mexico. Part III. Charadriiformes. U.S. Fish and Wildlife Service, Office of Biological Services, Washington, D.C. FWS/OBS-83-30. xvi \& 853 pp.

Clapp, R. B., and W. L. Schipper

1990b. New records of birds for Kwajalein Atoll, Marshall Islands. Elepaio 50(2):11-14.

Clapp, R. B., and W. O. Wirtz, II

1975. The natural history of Lisianski Island, Northwestern Hawaiian Islands. Atoll Research Bulletin 186. x \& 196 pp.

Crossin, R. S.

1974. The Storm Petrels (Hydrobatidae). Smithsonian Contributions to Zoology 158:154-205.

Edwards, E. P.

1955. Finding birds in Mexico. Amherst, VA., E. P. Edwards \& Co. 101 pp.

Ely, C. A., and R. B. Clapp

1973. The natural history of Laysan Island, Northwestern Hawaiian Islands. Atoll Research Bulletin 171. xi \& 361 pp.

Erwin, R. M., G. J. Smith and R. B. Clapp

1986. Field investigations of the biology of Common Terns wintering in Trinidad: a further look. Journal of Field Ornithology 57(4):300-308.

Glass, P. O., J. D. Reichel, T. O. Lemke, R. B. Clapp, G. J. Wiles, D. T. Aldan, and T.

K. Prat

1990. New migrant and vagrant bird records for the Mariana Islands, 1978-1988. Micronesica 23(1):67-89.

Gould, P. J.

1974. Sooty Tern (Sterna fuscata). Smithsonian Contributions to Zoology 158:6-52.

Gould, P. J., W. B. King, and G. A. Sanger

1974. Red-tailed Tropicbird (Phaethon rubricauda). Smithsonian Contributions to Zoology 158:206-231.

Howe, M. A., R. B. Clapp, and Journal of S. Weske

1978. Marine and Coastal Birds. MESA New York Bight Atlas Monograph 31. New York Sea Grant Institute, Albany, New York. 87 pp. 
King, W. B.

1974. Wedge-tailed Shearwater (Puffinus pacificus). Smithsonian Contributions to Zoology 158:53-95.

Marks, J. S., R. L. Redmond, P. Hendricks, R. B. Clapp and R. E. Gill, Jr.

1990. Notes on longevity and flightlessness in Bristle-thighed Curlews. Auk 107(4):779-781.

Michener, M. C., J. S. Weske, and R. B. Clapp

1964. A breeding colony of Agami Herons in Veracruz, Mexico. Condor 66(1):7778.

Mostello, C. S., N. A. Palaia, and R. B. Clapp

2000. Gray-backed Tern (Sterna lunata). The Birds of North America No. 525. 28 pp. (A. Poole and F. Gill, eds.). The Birds of North America, Inc., Philadelphia, PA.

Rauzon, M. J., C. S. Harrison and R. B. Clapp

1984. Breeding biology of the Blue-gray Noddy. Journal of Field Ornithology 55(3):309-312.

Sanger, G. A.

1974a. Black-footed Albatross (Diomedea nigripes). Smithsonian Contributions to Zoology 158:96-128.

Sanger, G. A.

1974b. Laysan Albatross (Diomedea immutabilis). Smithsonian Contributions to Zoology 158:129-153.

Saunders, A. A.

1951. A guide to bird songs, descriptions and diagrams of the songs and singing habits of land birds and selected species of shore birds. Garden City, NY, Doubleday. xiv \& 307 pp.

Schreiber, R. W.

1977. Maintenance bekhavior and communication in the Brown Pelican. American Ornithologists' Union Monograph 22. 78 pp.

Schreiber, R. W.

1979 Reproductive performance of the Eastern Brown Pelican, Pelecanus

occidentalis. Los Angeles Natural History Museum Contributions to Science 317:1-43.

Seto, N. W. H., Journal of W. Warham, N. L. Lisowski, and L. Tanino

1996. Jouanin's Petrel Bulweria fallax observed on Sand Island, Midway Atoll.

Sutton, G. M. Colonial Waterbirds 19(1):132-134.

1951. Mexican birds: first impressions. Norman, Univ. Oklahoma Press. xv \& 282 pp.

Sutton, G. M.

1972. At a Bend in a Mexican River. Paul S. Eriksson, Inc., New York. 184 pp. Woodward, P. W.

1972. The natural history of Kure Atoll, Northwestern Hawaiian Islands. Atoll Research Bulletin 164. xxi and 318 pp.

Woodward, P. W. and R. B. Clapp

1969. First records of Baird's Sandpiper from the central Pacific. 'Elepaio 30(3):25. Worcester, D. C.

1911. Hybridism among boobies. Philippine Journal of Science and Biology 6:179. 


\section{$2 \mathrm{BHL}$ Biodiversity Heritage Library}

Clapp, Roger B. 2001. "Autobiographical notes or fun with field work." Atoll research bulletin 494, 53-78.

View This Item Online: https://www.biodiversitylibrary.org/item/123661

Permalink: https://www.biodiversitylibrary.org/partpdf/83111

\section{Holding Institution}

Smithsonian Libraries

\section{Sponsored by}

Biodiversity Heritage Library

\section{Copyright \& Reuse}

Copyright Status: In Copyright. Digitized with the permission of the rights holder Rights Holder: National Museum of Natural History, Smithsonian Institution License: https://creativecommons.org/licenses/by-nc-sa/4.0/ Rights: http://www.biodiversitylibrary.org/permissions/

This document was created from content at the Biodiversity Heritage Library, the world's largest open access digital library for biodiversity literature and archives. Visit BHL at https://www.biodiversitylibrary.org. 